\title{
Materializing Exposure: Developing an Indexical Method to Visualize Health Hazards Related to Fossil Fuel Extraction
}

\author{
SARA WYLIE ${ }^{1}$ \\ NORTHEASTERN UNIVERSITY \\ ELISABETH WILDER \\ NORTHEASTERN UNIVERSITY \\ LOURDES VERA \\ NORTHEASTERN UNIVERSITY \\ DEBORAH THOMAS \\ SHALE TEST \\ Megan MCLAughlin
}

\begin{abstract}
How can STS researchers collaborate with communities to design environmental monitoring devices that more effectively express their experiences and address gaps in regulation? This paper describes and shows the results of a novel method of visualizing environmental emissions of corrosive gases such as hydrogen sulfide $\left(\mathrm{H}_{2} \mathrm{~S}\right)$ exposure using photographic paper. $\mathrm{H}_{2} \mathrm{~S}$ is a neurotoxic and flammable gas that smells like rotten eggs and is frequently associated with oil and natural gas extraction. Communities living with oil and gas development in Wyoming report odors of rotten eggs and describe symptoms of $\mathrm{H}_{2} \mathrm{~S}$ exposure. $\mathrm{H}_{2} \mathrm{~S}$ is recognized as an acute and chronic threat to human and environmental health and oil and gas companies are required to have plans in place to prevent and respond to accidental, high concentration releases of $\mathrm{H}_{2} \mathrm{~S}$.

\footnotetext{
1 Sara Wylie, Email: s.wylie@neu.edu

Copyright (c) 2017 (Sara Wylie, Elisabeth Wilder, Lourdes Vera, Deborah Thomas, and Megan McLaughlin). Licensed under the Creative Commons Attribution Non-commercial No Derivatives (by-nc-nd). Available at estsjournal.org.
} 
They are not, however, required to monitor, report or prevent routine daily emissions. Yet $15-25 \%$ of the oil and gas wells in the US are predicted to contain $\mathrm{H}_{2} \mathrm{~S}$, and some communities surrounded by multiple wells report chronic, routine exposure. Chronic exposure is difficult to represent with current tools for monitoring $\mathrm{H}_{2} \mathrm{~S}$ because they are designed to measure acute workplace exposure. Informed by STS theories of black boxes and regimes of imperceptibility that focus on the need to revise not only regulations but also material tools of science, this paper describes the development of an indexical approach to visualizing this hazard. In indexical design, the reactive sensing element of a scientific instrument is brought to the foreground. The silver in the photopaper is an index as it tarnishes with $\mathrm{H}_{2} \mathrm{~S}$ exposure. Discolored tests strips can be arranged together to form data-rich maps of the exposure landscape where this discoloration both represents how the gas spreads through a space and is a physical trace of the gas. Preliminary results in the form of data-rich maps show that regulating $\mathrm{H}_{2} \mathrm{~S}$ emissions as primarily accidental is inappropriate and fails to adequately protect human health.

\section{Keywords}

fracking; oil; natural gas; citizen science; civic science; open source hardware

\section{Introduction}

Patricia Baker and her husband, John², bought their ranch in the early 2000's to raise meat goats and cattle between Deaver and Frannie, Wyoming. Like many properties in Wyoming, their ranch included oil wells, owned and operated by a company that had leased the mineral rights before the Bakers bought their property. Patricia and John discovered an oil pipeline leak within the first month of living on their new property. When the pipeline broke, Patricia says, "the raw oil smell ma[d]e my nose and my eyes burn" (Thomas 2014). During the next few years, pipeline leaks and infrastructure failures continued to occur on their ranch. They fear that hydrogen sulfide $\left(\mathrm{H}_{2} \mathrm{~S}\right)$ corroded the metal pipelines and associated equipment, resulting in the oil leaks. $\mathrm{H}_{2} \mathrm{~S}$ is a corrosive gas formed during the decomposition of dead plant and animal material. It can be produced alongside oil and gas as high-sulfur kerogens (organic material in sedimentary rocks that are the precursor to fossil fuels) are compressed and heated deep below the surface (Skrtic 2006).

\footnotetext{
${ }^{2}$ Names have been changed and identifying information removed.
} 
The Bakers regularly experience dizziness, chest pain, and fatigue (Thomas 2014), all symptoms associated with exposure to $\mathrm{H}_{2} \mathrm{~S}$ (Skrtic 2006). Patricia says that the emissions "[make] my lungs hurt, my chest hurt, [make] me real sleepy, and dummy. Kind of dizzy and just not all there." She also notes that emissions are stronger and her symptoms worsen when prevailing winds come from the well locations. Unusually high rates of miscarriage and premature death occurred in their goat herd when they were moved into the pastures close to the oil pads and discharge canals. Despite multiple complaints to the oil company and the Wyoming Oil and Gas Conservation Commission (the state agency that regulates $\mathrm{H}_{2} \mathrm{~S}$ from oil and gas operation) about this litany of health problems and property damage, the Bakers have received little relief to date. Warning signs for $\mathrm{H}_{2} \mathrm{~S}$ are required to be posted on public land where the toxic gas is known to be present but no monitoring for the gas is done at any wellheads, infrastructure, or discharges in Wyoming. The rusted $\mathrm{H}_{2} \mathrm{~S}$ warning signs around the Bakers' oil wells offer physical witness to the presence of this corrosive, toxic gas. Only the downturn of oil prices has slowed the development and lessened the Bakers' impacts from $\mathrm{H}_{2} \mathrm{~S}$.

How, in the context of regulatory neglect, can residents like the Bakers understand, represent, and address their exposure to contaminants like $\mathrm{H}_{2} \mathrm{~S}$ ? This problem is common in communities wrestling with industrial exposures that currently have no affordable, systematic way to monitor or document their exposure (B. Allen 2003; Auyero and Swistun 2009). In response, communities are innovating new forms of Do-It-Yourself (D.I.Y.), street science and community based research (Corburn 2005; Ottinger 2010a) and scientists are changing their methods to collaborate with communities in environmental health research (B. Allen 2004). STS researchers are also changing their methods to begin actively doing "undone science $^{3}$ by redesigning tools for environmental science research based on an analysis of the power dynamics embedded in current technologies (Wylie et al. 2014; Liboiron 2015; Ratto 2011; Gabrys 2016). This paper theorizes our efforts to develop a low-cost method to visualize and study low-level, chronic exposures to $\mathrm{H}_{2} \mathrm{~S}$ in order to enable exposed communities to affordably map and identify contamination of their collective environments. By practicing STS to alter the process of monitoring and representing industrial emissions, we aim to more effectively capture and represent communities' exposure experiences, which Adams et al. describe as the "embodied, personal experience and understanding of chronic exposure to environmental pollutants" (2011). This method for sensing and mapping $\mathrm{H}_{2} \mathrm{~S}$ offers an "indexical" approach to sensing that affords

${ }^{3}$ Frickel et al. define "undone science" as "areas of research identified by social movements and other civil society organizations as having potentially broad social benefit that are left unfunded, incomplete, or generally ignored" (2010). 
new political possibilities for representing environmental contamination. ${ }^{4}$

In collaboration with Wyoming residents and Public Lab, an online community that develops open source tools for community-based environmental monitoring, we are developing an alternative, affordable approach to mapping $\mathrm{H}_{2} \mathrm{~S}$ and tracking community exposure (Wylie 2011; Wylie et al. 2014; Wylie and Albright 2014; Wylie and Thomas 2014; Dosemagen, Warren, and Wylie 2011). Such a tool could be useful to communities across the US in "sour" oil and gas fields that are contaminated with $\mathrm{H}_{2} \mathrm{~S}$.

Between 2001 and 2014, natural gas and oil development in the US increased exponentially to make the US the largest producer of oil and gas worldwide (Smith 2014). It is now estimated that 15 million Americans live within one mile of an oil or gas well (Gold and McGinty 2013), and 15-25\% of those wells may contain $\mathrm{H}_{2} \mathrm{~S}$ (Skrtic 2006). ${ }^{5}$ Nonetheless, $\mathrm{H}_{2} \mathrm{~S}$ emissions from oil and gas production wells are not federally regulated or monitored, and state regulations are often very weak when present (Skrtic 2006). Moreover, standard monitoring tools and regulatory frameworks approach $\mathrm{H}_{2} \mathrm{~S}$ exposure as primarily a workplace hazard, although emissions can extend to the communities who live near $\mathrm{H}_{2} \mathrm{~S}$-generating industries (Skrtic 2006; Wing et al. 2008; Kilburn 2012; Schinasi et al. 2011; Finnbjornsdottir et al. 2016).

STS can be operationalized to produce environmental monitoring tools that render community members' embodied exposure experiences more perceptible. We describe how two canonical STS ideas can inform the redesign of approaches to environmental sensing: black boxing, where debates are artifactually settled by hiding how facts are made and scientific devices operate (Latour 1987), and regimes of imperceptibility, where regulations and the construction of tools for detecting chemical exposures serve to exclude and dismiss the embodied harms experienced by exposed people (Murphy 2006). By unfolding black boxed scientific instruments, the sensing element that the detection of contaminants depends on can be brought to the surface in a process we describe as indexical design (Offenhuber and Telhan 2015). All sensing devices, such as the cloud chambers used in physics to detect the path of particles described by Galison (1997), rely on a reactive medium, or an index, that is physically altered in a predictable way by the signal it detects. For instance, the mercury in a thermometer expands

${ }^{4}$ Indexical design is a term developed by Dietmar Offenhuber to describe visualization techniques that rather than representing data iconographically visualize a trace of the thing itself such as how foot-prints trace the path of animal (Offenhuber and Telhan 2015).

${ }^{5}$ This boom in production caused a glut in supply that drove prices down and slowed the rate of extraction (Bowler 2015). However, the infrastructure for extraction has already expanded to communities across the US, and the market bust creates conditions where wells may be improperly maintained, potentially worsening fugitive $\mathrm{H}_{2} \mathrm{~S}$ and other gas emissions. 
predictably as temperature changes. ${ }^{6}$ In indexical design, rather than black boxing an instrument's index, the sensing elements are brought to the foreground (Peirce et al. 1960). We argue that an indexical approach to instrument design could assist in legitimizing the embodied experiences of exposures that are currently obscured by regimes of imperceptibility.

Specifically, we have worked with communities to adapt and validate a low cost method for visualizing ambient corrosive gases like $\mathrm{H}_{2} \mathrm{~S}$ gas in an area and geographically mapping them using photographic paper (Horwell et al. 2005; Horwell et al. 2004). ${ }^{7}$ The silver in the photopaper corrodes and darkens with exposure to sulfuric air contaminants like $\mathrm{H}_{2} \mathrm{~S}$. The method was originally developed to map $\mathrm{H}_{2} \mathrm{~S}$ from volcanoes (Horwell et al. 2005; Horwell et al. 2004). Our major adaptations from the original method are 1) to use it to assess industrial $\mathrm{H}_{2} \mathrm{~S}$ emissions 2) to develop a process for communities to validate and quantify the assay's qualitative results and 3) to share the method with an online community. ${ }^{8}$ The photopaper is an index that simultaneously contains and visually conveys an aspect of the object that the tool senses. The photopaper can provide a longitudinal view of $\mathrm{H}_{2} \mathrm{~S}$ (and other corrosive gases) concentrations when exposed to ambient air, thereby approximating human exposures in a location, and then it can be mapped to show hot spots for emissions. These maps make visible community exposurelandscapes by revealing how $\mathrm{H}_{2} \mathrm{~S}$ spreads from privately owned industrial places into public spaces and residential properties where individuals are likely to smell or experience health symptoms related to $\mathrm{H}_{2} \mathrm{~S}$ exposure. In epidemiology, exposure has a more specific definition than in common parlance and refers to a concentration that varies over time while in contact with receptor. As the photopaper themselves are receptors, standing in for an exposed person, we use the term exposure-landscapes to describe the photopaper maps because the maps reveal how a person might be exposed if they traveled in the region mapped.

Through a case study of using this tool on the Bakers' property in Wyoming, we show how this indexically designed $\mathrm{H}_{2} \mathrm{~S}$ sensor challenges the regulatory assumption that $\mathrm{H}_{2} \mathrm{~S}$ emissions from oil and gas wells are accidental and periodic by illustrating that in this case they

\footnotetext{
${ }^{6}$ As discussed in Galison (1997), the trace recorded by the index is not the object itself, but only a partial imprint that should not be misrecognized as the totality of the thing.

${ }^{7}$ Along with other air sampling methods targeted towards $\mathrm{H}_{2} \mathrm{~S}$ and VOCs such as radiello tubes, corrosion coupons, Tedlar bags, and SUMMA canisters.

8 This paper discusses preliminary results from this ongoing research project and theoretical issues relevant to STS audiences. The process for validating and quantifying this assay will be published for scientific audiences in a peer-reviewed journal and online in an open source, accessible format for impacted and/or interested communities.
} 
are chronic and routine. We explore how the "data-rich" map of this exposure landscape makes perceptible their exposures in a manner that compliments rather than dismisses their reported exposure experiences as is typical in a regime of imperceptibility.

\section{The Invisibility of Chronic Exposures and Construction of Regulatory Neglect}

$\mathrm{H}_{2} \mathrm{~S}$ occurs naturally around volcanoes, sulfur springs, undersea vents, and stagnant bodies of water. It is also associated with municipal and industrial sources such as sewage treatment plants, concentrated animal feeding operations, pulp and paper mills, and oil and gas production sites. Acute exposure to high levels of $\mathrm{H}_{2} \mathrm{~S}$ can cause headaches, seizures, nervous system damage, paralysis, and death (Skrtic 2006), and is a leading cause of workplace injury in the United States. Between 2011 and 2014, 1,157,410 contracted workers incurred occupational injuries or illnesses from $\mathrm{H}_{2} \mathrm{~S}$ gas poisoning, 19 of which were fatal (US Department of Labor, Bureau of Labor Statistics 2015). Considering these statistics, $\mathrm{H}_{2} \mathrm{~S}$ has been primarily regulated as a workplace hazard, resulting in regulations tailored to emergency notification of acute high dose exposures. However, as oil and gas extraction grows, it is increasingly possible that many communities could be chronically exposed to $\mathrm{H}_{2} \mathrm{~S}$.

Long-term exposure to low levels of $\mathrm{H}_{2} \mathrm{~S}$ poses a serious hazard to human health (Legator et al. 2001; Kilburn, Thrasher, and Gray 2010). One human epidemiological control case study compared populations in Texas and Hawaii, where $\mathrm{H}_{2} \mathrm{~S}$ is naturally present in low concentrations. The exposed groups' odds of suffering a central nervous system problem were found to be 12.7 times higher than the control groups (Legator et al. 2001). Another study in New Mexico showed similar patterns (Kilburn, Thrasher, and Gray 2010). In the Southeast US, Centers for Disease Control and Prevention (CDC) researched $\mathrm{H}_{2} \mathrm{~S}$ emitted from drywall manufactured in China and found health effects at levels as low as $1.4 \mathrm{ppb}$. This value is approximately 7,100 times lower than the recommended workplace exposure established by the National Institute for Occupational Safety and Health (NIOSH) of 10,000 ppb for 10 minutes (J. Allen et al. 2012). Air sampling surveys measured an average $\mathrm{H}_{2} \mathrm{~S}$ level of $0.6 \mathrm{ppb}$ in 41 homes complaining of odor, corrosion, and health problems. Complaints included asthma, ear nose and throat symptoms, and central nervous system effects such as headaches and dizziness (J. Allen et al. 2012, 118; Jäppinen et al. 1990).9 In 2011, the EPA also concluded that chronic, low dose exposures could be harmful

\footnotetext{
${ }^{9}$ Although toxicants such as formaldehyde and carbon disulfide were also present in the Chinese drywall, residents experienced health effects previously shown to be associated with $\mathrm{H}_{2} \mathrm{~S}$ exposure such as bronchial obstruction and neurological symptoms (J. Allen et al. 2012).
} 
to human health (Environmental Protection Agency 2011). Despite these conclusions, oil and gas facilities are not required to prevent or report $\mathrm{H}_{2} \mathrm{~S}$ emissions (Environmental Protection Agency 2011).

The exemptions for $\mathrm{H}_{2} \mathrm{~S}$ are emblematic of regulatory capture by industrial interests (Laffont and Tirole 1991). Calls for regulation of $\mathrm{H}_{2} \mathrm{~S}$ date back to the late 1980s when the Senate Committee on Environment and Public Works heard testimony about $\mathrm{H}_{2} \mathrm{~S}$ emitted from oil and gas wells in North Dakota, which resulted in the deaths of cattle as well as resident evacuations and hospitalizations (Morris 1997). Consequently, $\mathrm{H}_{2} \mathrm{~S}$ was placed on EPA's list of Hazardous Air Pollutants (HAPs), which are subject to national emissions standards and federal oversight under Section 112(b) of the Clean Air Act (Skrtic 2006). Chemicals regulated under 112(b) are required to be monitored and reported to the Toxic Release Inventory (TRI), which is publicly available online.

Lobbying from the oil and other industries removed $\mathrm{H}_{2} \mathrm{~S}$ from the HAPs list, leading to its less stringent regulation as an Extremely Hazardous Substance (EHS). Extremely Hazardous Substances are regulated under Section 112(r) of the Clean Air Act of 1990 (Morris 1997), and $\mathrm{H}_{2} \mathrm{~S}$ emitting facilities only need to have plans in place to "prevent and respond to accidental releases" (Skrtic 2006). A former EPA official quoted in The Houston Chronicle called this removal of $\mathrm{H}_{2} \mathrm{~S}$ from the list of HAPs a "political deal" that the EPA made with Texas oil companies (Morris 1997).

In 1992, the EPA attempted again to regulate $\mathrm{H}_{2} \mathrm{~S}$ more stringently by requiring TRI reporting. In response, the Chemical Manufacturers Association threatened the EPA with a lawsuit. They argued that there had not been "sufficient demonstration of hydrogen sulfide's chronic effects," (Morris 1997). Despite internal EPA memos advising the agency to "continue support for $\left[\mathrm{H}_{2} \mathrm{~S}^{\prime}\right]$ chronic neurotoxicity effects" (Morris 1997), the EPA formally recommended "no further legislation pertaining to routine $\mathrm{H}_{2} \mathrm{~S}$ emissions or accidental releases from oil and gas wells" (Environmental Protection Agency 1993). According to Assistant EPA Administrator Lynn Goldman, this was preferable to "going through costly and potentially protracted litigation" (Environmental Protection Agency 1994).

The administrative stay on $\mathrm{H}_{2} \mathrm{~S}$ reporting lasted 17 years until, in 2011, EPA finally officially concluded that $\mathrm{H}_{2} \mathrm{~S}$ "can reasonably be anticipated to cause chronic health effects in humans" (Environmental Protection Agency 2011, 64204). $\mathrm{H}_{2} \mathrm{~S}$ emissions must now be reported to the TRI by any facility that manufactures or processes more than 25,000 pounds or uses more than 10,000 pounds of $\mathrm{H}_{2} \mathrm{~S}$. However, reporting at oil and gas wells, impoundment pits where salty and oily water produced during extraction (produced water) is stored, and discharge canals 
is still not required (Environmental Protection Agency 2011).

This regulatory loophole contributes to a large gap in public health protections from $\mathrm{H}_{2} \mathrm{~S}$ exposure of communities living near oil and gas extraction. Additionally, $\mathrm{H}_{2} \mathrm{~S}$ is just one among many other associated hazards, and communities report numerous health effects coincident with oil and gas extraction (Moore et al. 2014). ${ }^{10}$ In Cleveland, Ohio, in 2008, $\mathrm{H}_{2} \mathrm{~S}$ from a newly drilled shale gas well leaked into a suburban home. Heavier than air, the gas knocked out a child. She was rushed to the hospital and treated for $\mathrm{H}_{2} \mathrm{~S}$ exposure. Neither the first responders nor the child's parents had any awareness of the hazard in their community prior to this incident (Wylie 2011). Another family with three drill rigs surrounding their property experienced "pungent odors of rotten eggs followed by severe headaches, nosebleeds and rashes" (Larson et al. 2011, 14) after oil and gas development began. They were advised to evacuate their home by their doctor. An air sample taken on their property found $\mathrm{H}_{2} \mathrm{~S}$ levels that were more than 185 times the level that EPA estimates would result in "increased risk of serious health effects," but regulatory agencies did not issue any violations (Larson et al. 2011,14). The family and other community residents made frequent reports of non-compliance to state and federal agencies but felt that "their concerns have fallen on deaf ears" after the nearby well operators simply blamed one another for the $\mathrm{H}_{2} \mathrm{~S}$ contamination (Larson et al. 2011,15).

\section{Designing with STS Principles}

The Bakers and similarly situated families across the country face at least two structural challenges in making their exposures visible and actionable. First, unlike the industry they are encountering, they have neither the social nor financial capital to compel regulations. Secondly, the technologies of science required to make their experiences matters of fact are absent (Shapin and Schaffer 1985). In response to these twin challenges, this project designs new material technologies of science that produce more embodied forms of data collection and representation to better express community exposure experiences that are often disputed by regulators in the interest of the oil and gas industry (Shapin and Schaffer 1985; Wylie et al. 2014; Wylie and Albright 2014).

STS forces attention to how the structure of science itself, from the materiality of research tools (Ottinger 2010b; Wylie and Albright 2014; Wylie et al. 2014; Wylie and Thomas 2014) to the

\footnotetext{
10 We focus on $\mathrm{H}_{2} \mathrm{~S}$ because its hazards are well known and an extensive amount of work has been conducted on various air pollutants related to oil and gas production. Communities report many health effects linked with pollutants from oil and gas extraction, many cases that are specifically related to $\mathrm{H}_{2} \mathrm{~S}$.
} 
accepted forms of data (Murphy 2006; B. Allen 2003), can perpetuate the production of knowledge favorable to industry. ${ }^{11}$ In this case, the focus on $\mathrm{H}_{2} \mathrm{~S}$ as an acute workplace hazard, rather than a chronic pollutant released by oil and gas production, has created an ecology of tools and acceptable forms of data that structurally exclude communities exposed to chronic, low doses. An example of a tool commonly used in industrial and regulatory settings is the goldstandard occupational device for monitoring $\mathrm{H}_{2} \mathrm{~S}$ : the Jerome meter, from Arizona Instrument, LLC, which we purchased as part of our project validating the use of photographic paper to track industrial emissions.

\section{Current Detection Tools and Processes Exclude Communities:}

Tools like the Jerome meter (henceforth, "the Jerome") make community exposures to $\mathrm{H}_{2} \mathrm{~S}$ less visible and less actionable by contributing to what Murphy describes as a regime of imperceptibility (Murphy 2006). The Jerome is designed for use by large organizations such as

\footnotetext{
11 There is an extensive STS literature on scientific devices and how they can be political actors even through the process of making seemingly neutral "matters of fact" (Shapin and Schaffer 1985). Shapin and Schaffer refer to scientific instruments as "material technologies" of laboratory science: these instruments set the physical stage for what will count as evidence in scientific discourse. Arguing with evidence produced by a scientific instrument frequently requires use of the instrument in a way that limits access to the debate. Their historical analysis shows how Robert Boyle, the founder of the experimental program in science, strategically used his air pump to determine what forms of evidence could be used to dispute the existence of a vacuum. Entering into a debate with Boyle required producing material forms of evidence via instrumentation rather than via theoretical arguments. This established laboratories as the proving grounds of scientific debates. Feminist science studies scholars, along with historians of biology, have further expanded on this theme by studying the way organisms and instruments do not precede scientific inquiry but rather are constructed as the "right tools for the job" through laboratory research (Haraway 1997; Kohler 1994; Traweek 1992; Clarke and Fujimura 1992). STS research has problematized universalizing truths produced from such instruments, as the laboratory is an ecology in itself where particularly forms of life and evidence are selected and indeed manufactured (Haraway 1997; Landecker 2007). For instance, fruit flies became the basis of genetic research because of their long history of cohabitation with humans and because of the suitability of their life-cycles to university-based research. Other organisms that do not have those traits have not become model organisms and are therefore excluded from experimental investigation (Kohler 1994). However, the "matters of fact" generated with such socio-technical constructs are often taken as universal truths. Additionally, it is frequently overlooked that in connection with corporate science, laboratories' research often serves to biomedicalize and commoditize solutions to social issues such as using model organisms to develop better treatments for asthma and cancer rather than preventing harmful exposures by limiting toxic pollution. The laboratory construction of instruments, including model organisms, is particularly problematic in toxicology where, as Murphy investigates, genetically standardized mice have come to stand for exposed humans so that harms experienced by exposed communities are dismissed (2006) and model organisms are used to develop profitable individual treatments to industrially related illnesses (Jain 2013).
} 
universities and companies. For most communities, it is not easily available for rent and prohibitively expensive at $\$ 15,000$ with required yearly calibrations costing $\sim \$ 700$. Additionally, verifying that the Jerome is operating correctly, a key step in creating credible data, requires exposing it to a known amount of $\mathrm{H}_{2} \mathrm{~S}$. This involves a second device called a Functional Test Module (FTM), which uses a small tube of $\mathrm{H}_{2} \mathrm{~S}$ provided by the instrument manufacturer. Ironically for communities routinely exposed to unregulated emissions of $\mathrm{H}_{2} \mathrm{~S}$, although the $\mathrm{H}_{2} \mathrm{~S}$ tube contains a concentration of $\mathrm{H}_{2} \mathrm{~S}(0.25 \mathrm{ppm})$ that is well below many short-term regulatory thresholds, it can only be mailed through a Hazmat-certified shipping account. According to Title 49 Code of Federal Regulations, use of such an account requires hazardous materials training (Department of Transportation 2012). Many communities and even university departments ${ }^{12}$ do not have this type of training. ${ }^{13}$

The inaccessibility of the instrument for communities extends into its physical design. Like most analytical technologies, how the meter works is often a mystery to users who must rely on engineers at Arizona Instrument to troubleshoot issues. We have encountered numerous challenges to using the meter in the field, including its sensitivity to shifts in humidity, winds, and air temperature. This required us to use special tube or filter attachments when working in a location with high humidity or moving between an air-conditioned car and the hot air outside. We then had to send it back for calibration after we noticed inconsistent readings and were unsure if it was functioning properly. Even large organizations have struggled with the accuracy and reliability of the meter. In 2005, the environmental department of a city that owns and operates multiple wastewater treatment plants realized that hydrogen sulfide readings were high even though the carbon adsorbers (which eliminate volatile organic compounds) in their facilities had recently been replaced. This led to a study testing the validity of Jerome meter readings, which found that all 15 Jerome meters tested had relative standard deviation values exceeding the manufacturer's precision limit (Morton 2008).

Both literally and figuratively, this device is a black box--a technology whose inner workings are opaque, making it difficult for users to question its findings (Latour and Woolgar 1986). Latour developed the metaphor of black boxing after ethnographically encountering the physical black box of a mass spectrometer. He remarks that: “The mass spectrometer constitutes a

\footnotetext{
12 As Northeastern University at the time of this project did not have permission to ship hazardous materials, all of our shipments of the Jerome Meter routed through Harvard University's shipping account. This was possible as a Harvard School of Public Health Fellowship funded the project. Without this institutional connection, large parts of this project would have been impossible to conduct.

13 UPS training costs $\$ 575-\$ 950$ per person (United Postal Service 2017).
} 
black box...The large prototype of the middle thirties has now become a compact and commonplace piece of equipment, which incorporates a computer to carry out most of the initial interpretations" (Latour and Woolgar 1986, 150). Similarly, the Jerome is a physical black box and it metaphorically functions as a black box, offering a numeric assessment of ambient $\mathrm{H}_{2} \mathrm{~S}$ concentrations that the user cannot readily verify or contest.

\section{STS Informed Design}

Beyond Black Boxes-Creating Participatory Sensory Apparatuses through Indexical Design

Within an instrument that has been black boxed, the interpretation of what a change to the index means is computed by the device without the user's input, and the steps taken to measure this concentration are opaque to the user. In Latour's spectrometer example, where the index or "inscription (the spectrum) is obtained by direct contact of the electron flow with the sampled molecules," a computer carries out "most of the initial interpretations" (Latour and Woolgar 1986, 150). Similarly, the Jerome detects $\mathrm{H}_{2} \mathrm{~S}$ by its adsorption and resulting change in electrical conductivity on a thin sheet of gold. Based on this change in conductivity, a proprietary formula is used by the instrument's computer to calculate the $\mathrm{H}_{2} \mathrm{~S}$ concentration in a sample of air and display it on a digital screen (Arizona Instrument, LLC 2015). This measurement is then taken to be the ambient concentration of $\mathrm{H}_{2} \mathrm{~S}$ gas in the location where the sample was taken. In contrast to the black boxing of the interpretative process within the Jerome, the indexical photopaper tool described in this paper unpacks the layers of verification, numerization, and inference that have been embedded within the Jerome meter to bring the indexical element to the surface.

In the photographic paper method, sheets of photographic paper are prepared in a darkroom and cut into small rectangular strips. The strips are placed inside cylindrical black canisters originally used for photographic film and then capped to prevent light exposure (as the silver in the photographic paper is light sensitive it is important that light not contaminate the paper). The canisters can be placed out in the field (upside down to prevent light contamination) and then uncapped. Ambient air circulates inside the canister, and the film of silver halide on the photopaper reacts with sulfuric gases in the air to form silver sulfide. The canisters are recapped for transport, and the photopaper is fixed in the darkroom by a regular fixative that binds and removes any unreacted silver and ensures that the photopaper is no longer light sensitive. The darker the photopaper strips appear, the more sulfur-containing corrosive gases they have been exposed to. Based on the degree of darkening participants can visually assess and map them to discern the location of where higher levels of corrosive gases were detected. While the Jerome 
meter is clearly important for providing near real-time concentrations of $\mathrm{H}_{2} \mathrm{~S}$, the photopaper approach provides learning and adaptation opportunities as well as data analysis and visualization possibilities that the Jerome cannot readily provide.

Despite their significant differences, the Jerome meter and the photopaper both detect $\mathrm{H}_{2} \mathrm{~S}$ by a similar method-the corrosion of a metal. However, rather than hiding the index away from the user in a black box, the photopaper method puts the users directly in contact with the sensor. By working directly with the index, the photopaper affords different possibilities for both how participants engage with the research tool and how its data are visualized. Putting the indexical material physically in people's hands underlines that sensing is at root a physical, embodied activity that can be correlated to their embodied experience of exposure and opened to adaptation and redesign.

\section{Indexical Design: A Physical Record for Further Analysis}

By making the indexical aspect of the monitoring process accessible and obvious to the user, the photopaper method makes the contingency of the sensing process more apparent. Both the silver and gold film used in the Jerome react to corrosive gases other than hydrogen sulfide. However, with the numeric readout on the Jerome, there is no way to contest or double check that the device is responding only to $\mathrm{H}_{2} \mathrm{~S}$. Interferences with the gold sensor on the Jerome meter include: chlorine, ammonia, $\mathrm{NO}_{2}$ (commonly found along roadways), and most mercaptans (organic sulfur compounds or "thiols"). While the manufacturer considers these interferences to be rare, additional filters for chlorine and ammonia are available for purchase (Arizona Instrument, LLC 2015). The silver in the photopaper has a similar profile of potentially interfering compounds (Horwell et al. 2004).

The gold film index is screwed shut inside the Jerome meter's black box and inaccessible to the user who therefore cannot further query the sample itself to assess the accuracy of the meter's reading. The physical record of what the Jerome senses is erased following its use, particularly when the gold film is regenerated (i.e. heated to remove any corrosion) so the device can be used again. By contrast, the photopaper provides a physical record that, once fixed in a darkroom, can be further analyzed as a scientific sample. For instance, using X-ray fluorescence (XRF) individual elements (but not compounds) can be identified within solid or liquid samples by analyzing the intensity of X-rays emitted by the material (Lodge 1988). We are currently developing an XRF based method to identify and quantify the gases causing the corrosion of photopaper. 


\section{From Instrument Users to Participating in a Sensing Apparatus}

The photopaper method radically reduces the cost of detecting hazardous gases like $\mathrm{H}_{2} \mathrm{~S}$ and can be made using readily available materials. The components needed to build the tool are film canisters and photographic paper, tape, metal stakes, labels, and permanent markers. All of these components can be easily and affordably obtained at local stores or online for a total cost of approximately $\$ 1$ per canister.

This tool's methods and results have been shared online since the project began in 2011. ${ }^{14}$ We wrote instructions for making and using the photopaper tool in an online how-to guide available on Public Lab's 15 website. The guide includes the materials needed to construct the tool, where to find them, how to set up the darkroom, and step-by-step instructions outlining how to prepare the strips, assemble the canisters, set up the canisters, and process the exposed strips. At Northeastern University, we collaborated with the photography Department of Art+Design to use their darkroom, but a makeshift darkroom can also be used. The only hazardous component in developing the test strips is the fixative that absorbs any remaining silver halide in the photopaper and must be disposed of as hazardous waste. In sum, the financial and informational barriers to using the photopaper method are far fewer than for the Jerome meter.

Placing the sensing element in the hands of the user, the photopaper tool makes the user a more active part of the experimental apparatus rather than simply a reader of a monitor. For instance, to confirm internal validity of the photopaper's findings, the user must place duplicates in the field along with unexposed test strips. Duplicates confirm the replicability of the strips results and blank unexposed test strips confirm that changes to the strips are due to exposure to air in the field. These processes engage participants in validation of their data in contrast to the Jerome meter, where control and interpretation processes are embedded within the black box. By employing the photopaper approach, participants actively develop the results themselves and can adapt the sensing process of the photopaper tool to their needs. For instance, users can tinker

\footnotetext{
${ }^{14}$ Development and design for the photopaper tool can be found on Public Lab's website at: https:// publiclab.org/wiki/hydrogen-sulfide-sensor. Some community monitoring results are not available online because the community preferred to wait until peer-reviewed versions of the data were published prior to making results publicly available. Additionally, other participants in the project feared identification and chose to participate privately in their own monitoring projects.

15 Public Lab is an online open source hardware and software community for developing DIY environmental monitoring tools. Public Lab mimics and torques norms of experimental laboratory sciences to develop new social, literary, and material tools for science (Wylie et al. 2014).
} 
with the experimental design, choosing how long to leave the strips in locations to expand the window of analysis, whereas the operating time for the Jerome remains the same for each sample, at approximately 52 seconds, as determined by its manufacturer.

Users can also develop alternative containers and indexical mediums that change how the data are represented. Researchers in Iowa studying $\mathrm{H}_{2} \mathrm{~S}$ emissions from concentrated animal feeding operations developed an alternative to the film canister container that uses a cardboard box (Kornblug 2014). This simple change in housing for the photopaper could be expanded on to create artistic performances that indexically illustrate exposures. For instance, imagine a performance using larger sheets of photopaper housed in large dark boxes where an image would emerge over the exposure time. The method could draw on land-art performances and combine them with bio-art projects like those of Heather Ackroyd and Dan Harvey, who grew sheets of photoactive grass where images emerged over time (Wallis and Kastner 2010). ${ }^{16}$ Using large photographic sheets or sheets of silver to visualize emissions and exposures over time, the user can build on the medium of photography for witnessing and recording while using it to visualize the currently invisibilized exposures that pervade communities. Such a performance would change the social process of research by calling attention to a community's efforts to monitor industry. Rather than the emissions being the known but invisible threat, the monitoring itself becomes the visible activity where the results are invisible to the polluting industry. Such visible testing devices could loom around a facility, hiding what they detect until the user fixes the index inside and reveals the image of exposure over time. This could invert the current power dynamics in which industry controls the flow of information which is reported to federal agencies and then to the public.

\footnotetext{
${ }^{16}$ Ackroyd and Harvey developed a method of using grass to gradually fix large-scale photographic images http://www.ackroydandharvey.com/presence/. Other indexical approaches to environmental sensing developed by artists include Natalie Jermijenko's "OneTrees" project where she placed clones of a tree in different urban environments to physically demonstrate how the environments shaped the genetically identical tree's development (Jeremijenko 2000). Compressing space rather than creating an indexical experiment that unfolds over time, Brother Nut used a industrial vacuum cleaner to collect air in Chinese cities and created bricks from the particulate matter (Buckley and $\mathrm{Wu}$ 2015). These bricks physically demonstrate the materiality of pollution. Both of these projects grasp the material and embodied expression of "data" that indexical design enables, however they lack the replicability and stability common to scientific instruments and methods. By virtue of being black boxed and integrated into everyday experimental practice, scientific instruments become "experimental conditions," the unquestioned tools that are employed in many laboratories (Rheinberger 1997). How can STS be part of building a stable infrastructure for continuing indexical forms of investigation that are suited to field science experiments, so that scholarship such Onetrees continue to be objects of inquiry? Unfortunately, the Onetrees project was largely forgotten because there was no long-term research infrastructure to follow trees' actual development and create a foundation for further discovery from this project (Shea 2014).
} 


\section{Visibly Challenging Regimes of Imperceptibility by Mapping Landscapes of Exposure}

The indexicality and performativity of the photopaper method potentially challenge the imperceptibility of low-dose exposures and shift the register of social debate from the emissions concentrations to their reach across landscapes and communities. As architect Nerea Calvillo argues, monitoring devices have different "performative capacities" suited for different contexts of measurement and audiences of the results from data collected (2014, 23). Presently, the "performative capacities" of most monitoring devices for $\mathrm{H}_{2} \mathrm{~S}$ are tailored to the regulatory focus on acute high dose exposures in workplaces. In particular, monitoring devices are tailored to ensure that Threshold Limit Values (TLVs), regulatory thresholds below which exposures are deemed safe, are not exceeded. (The effectiveness of TLVs in preventing chronic, long-term health effects is rarely evaluated based on real world exposures.) None of the current detection methods are designed to capture $\mathrm{H}_{2} \mathrm{~S}$ in small amounts or spread over a large area. ${ }^{17}$

In contrast, photopaper can be plotted to form what we describe as "data-rich maps" that show the relative intensity of corrosive sulfuric gases over time in a large geographic area. ${ }^{18}$ Once fixed and dried, exposed strips can be arrayed over a map of the testing area to show a landscape of the relative intensities of corrosive gases. This way, the photopaper offers a qualitative look at levels of $\mathrm{H}_{2} \mathrm{~S}$ and provides an easily readable assessment of where the gas may be found at higher and lower levels over a longer window of time, such as one or three weeks.

17 Designed as a portable monitor, the Jerome only provides data on $\mathrm{H}_{2} \mathrm{~S}$ found in the path of the user carrying it. Most devices monitor for exceedance of maximum exposure levels (called threshold limit values or TLVs) and are designed to prevent acute health effects such as knock-down (unconsciousness induced by a lack of oxygen). TLVs are established based on testing in controlled laboratory conditions with genetically homogeneous laboratory animals (Murphy 2006; Sellers 1997). The effectiveness of TLVs in preventing chronic, long-term health effects is rarely evaluated based on real world exposures. Yet in practice, exposure levels below TLVs are presumed safe and dismissed (Murphy 2004; Murphy 2006). Even if the Jerome were accessible to community members, the meter is unable to detect the low doses below 3 ppb that were associated with health hazards in the CDC study. Detection levels for the Jerome meter range from $0.003 \mathrm{ppm}(3 \mathrm{ppb})$ to $50 \mathrm{ppm}$ of $\mathrm{H}_{2} \mathrm{~S}$. The Jerome's detection limit is actually lower than that of the photopaper (30 ppb), however (Horwell et al. 2004). This issue is revisited as we discuss the need for an ecology of tools.

18 Mapping is a powerful tactic in environmental justice and anti-toxics work (Corburn 2005; B. Allen 2003). Community led mapping in Environmental Justice (EJ) typically involves mapping community health symptoms (B. Allen 2003) or the proximity and disproportionate presence of industrial risk (Corburn 2005). Since EJ claims rest on demonstrating the inequitable exposure of vulnerable or minority populations to environmental hazards, mapping is fundamental to making environmental inequity visible (Bullard and Wright 1990). This project builds on the tradition of lay mapping by creating a means of indexically mapping environmental contamination that expresses exposure risk in an embodied and charismatic fashion (Liboiron 2015). 


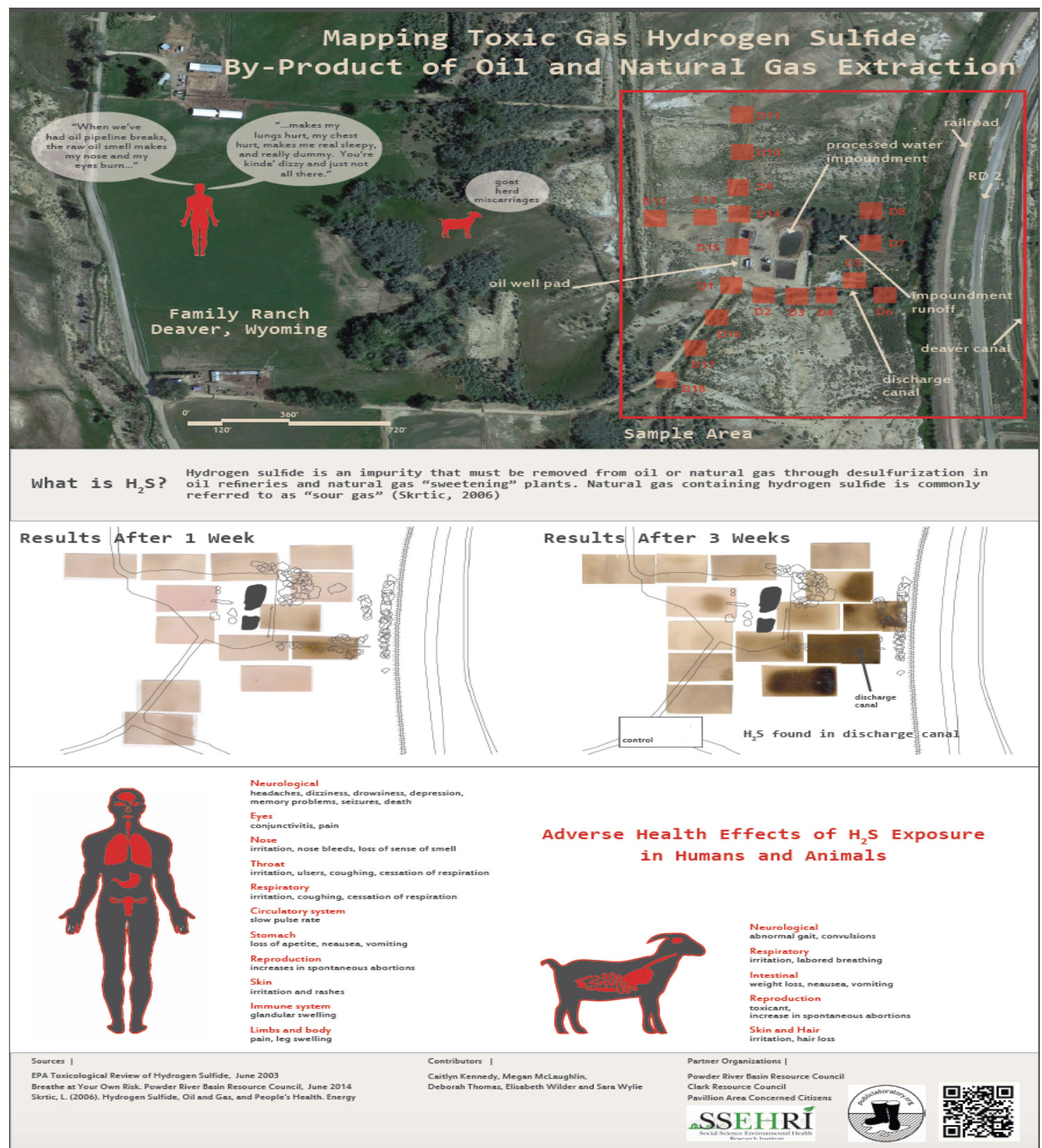

Figure 1: A data-rich map combining the Bakers' exposure experiences with photographic paper results developed by Megan McLaughlin for the 1st White House Maker Faire. (https:/ publiclab.org/notes/Sara/ 06-19-2014/ report-on-1st-white-house-maker-faire-june-18th-2014). 
The "data-rich map" can help illustrate relative spatial variability of the gas and relative concentrations of the gas at each location. The map is data-rich in two ways: 1) the individual strips, because they are indexes, can be queried for further information (for example with an XRF machine), and 2) when mapped together, they convey the data in a relatively easy to read form, as the darker a location's photopaper, the more corrosive gases are present. These charismatic representations of the landscapes of communities' exposures complement and contextualize numeric ways of representing $\mathrm{H}_{2} \mathrm{~S}$. These types of "charismatic data" challenge regimes of imperceptibility by making "a previously invisible form of harm visible, then focus on metrics that promote affective visions of crisis," informing action and advocacy (Pine and Liboiron 2015, 3148). The gas is visualized as a dark stain spreading across a landscape, increasing in intensity close to the source. Low doses are not excluded from such maps simply because they do not meet a predetermined threshold. ${ }^{19}$ Reported symptoms being experienced by residents of the area can be added to these maps, as is common in environmental justice work, to illustrate that symptoms are still occurring although levels may be low (B. Allen 2004; Corburn 2005). We made a map combining the Bakers' exposure experiences and photopaper results for the First White House Maker Faire, hosted by President Barack Obama, where we presented this project as part of Public Lab (see Figure 1). To highlight the effect of a gas spreading across the landscape, rather than mapping the strips on a statellite image of the location (where they can blend into the background), we mark the testing locations on a satellite map, then map the test strips on line drawings of the environment so as to highlight the discoloration of the strips (see Figure 1). An analog rather than iconic representation of exposure landscapes also potentially better captures exposure experiences.

Exposure to $\mathrm{H}_{2} \mathrm{~S}$ is noxious; its rotten egg smell physically ties the exposed person to a particular location and time. However, such smells do not travel well as representations. One needs to be present in a particular place to experience a smell; it cannot "travel" as an immutable mobile (such as a map that can move from location to location but be unchanged) to represent a place (Latour 1990). The human nose can detect $\mathrm{H}_{2} \mathrm{~S}$ at very low levels and is arguably the most sensitive sensor for $\mathrm{H}_{2} \mathrm{~S}$. However, the present scientific preference for numeric and visual data, as well as regulatory regimes built around TLVs, often dismisses the embodied experience as

\footnotetext{
19 Though the photopaper does have a detection limit of $30 \mathrm{ppb}$ (Horwell 2004), so concentrations below that level are not well mapped by this method. Thus, it is important to supplement this method with odor logs, as $\mathrm{H}_{2} \mathrm{~S}$ can be detected by the nose at $10 \mathrm{ppb}$ (Occupational Safety and Health Administration 2017).
} 
irrelevant or insufficient for action (Shapiro 2015). ${ }^{20}$ Unlike numeric representation of exposure, the photopaper test strip materially attests to exposures in a manner similar to the ways bodies experience it. The test strip stands in for the nose as a reactive, recording surface that, unlike a smell, can travel to represent exposures. STS scholars have extensively analyzed the preference for visualization in scientific research (Latour 1986; Latour 1990; Lynch and Woolgar 1990; Daston and Galison 2007; Dumit 2004; Tufte et al. 1998; Burri and Dumit 2008). ${ }^{21}$ Rather than attempting to directly subvert these norms, the photopaper tool offers a compromise: an index of the physical impacts of $\mathrm{H}_{2} \mathrm{~S}$ exposure that can charismatically express an exposure landscape and be further analyzed to legitimize embodied experience (see the introduction to this thematic collection for more on the necessity of compromise in creating useful data for advocacy). Our work in Wyoming illustrates how turning indexical measurements into data-rich maps, in combination with numeric data, powerfully make perceptible the problem of chronic exposure to $\mathrm{H}_{2} \mathrm{~S}$ from oil and gas development.

\section{Making Chronic Exposures Visible in Wyoming}

Collaborating with co-author Deb Thomas, a resident of Clark, Wyoming, we pilot tested the photopaper method as a way of documenting $\mathrm{H}_{2} \mathrm{~S}$ emissions during oil and gas extraction. Thomas began organizing and working with communities impacted by oil and gas development over fifteen years ago. Fossil fuel extraction transformed her life and community. Clark residents suffered from and reported countless impacts from the development that began in 1999. In 2006, a well blowout emitted hundreds of tons of VOCs and contaminated groundwater, drinking water wells, and air in her community, forcing the evacuation of twenty-five households including her own (Thomas 2006). There was no systematic evacuation plan in place, and the community still

\footnotetext{
20 An interesting exception to this trend is EPA's method 9, a process by which certified observers can witness and assess visible emissions from sources of pollution. In this case, as long as witnesses are certified, their observations can count as evidence (Environmental Protection Agency 2017).

${ }^{21}$ Haraway argues that the scientific preference for visualization rather than other forms of sensing is tied up with the ideal of impartial observation, producing what she describes as the "God's eye view from nowhere," where the assemblage required to create the visualization drops from the picture (1991). Dumit picks up this theme in his investigation of how brain scans travel as images of normal and schizophrenic brains (2004). Other senses are not as tied to the western separation between mind and body, upon which ideas of impartial observation rest. Smell in particular reminds us that our bodies are physically engaged in sensing (as they are in vision), since a smell is experienced, unlike an image, as actively entering the body from physical engagement with the object detected (Connor 2005). Our project plays into rather than undermines the preference for creating visual rather than auditory or olfactory scientific evidence by creating charismatic images of pollution.
} 
struggles with air and water contamination. Frustrated by blatant violations like the blowout, the failure of regulatory science to understand the health impacts occurring in her community, and lack of regulatory enforcement, Thomas turned to organizing a citizen science effort to generate data about exposures in her region of Wyoming. She believed that science would help make evident the daily hazards impacting her and her community's lives. This work, along with that of other impacted people across the country, led to the first peer-reviewed citizen science study of air quality impacts from oil and gas extraction and development (Macey et al. 2014).22

Thomas and Wylie began talking about issues from $\mathrm{H}_{2} \mathrm{~S}$ contamination during this citizen monitoring effort. Though $\mathrm{H}_{2} \mathrm{~S}$ contamination of the region's oil and gas fields is well known by local residents, there is no routine monitoring or research on its human and environmental health impacts. Thomas worked with impacted communities after learning about the possibilities of the photopaper tool to monitor $\mathrm{H}_{2} \mathrm{~S}$. Together, Thomas and other community residents used the photopaper tool in four locations: one on the Bakers' property, two along well trafficked public roads in large oil and gas fields, and one in a state park. The public roads and state park were chosen by area residents to investigate public $\mathrm{H}_{2} \mathrm{~S}$ exposures and environmental impacts. The Bakers volunteered to participate because of their personal experiences with $\mathrm{H}_{2} \mathrm{~S}$ from the oil extraction on their property.

Our research began on the Baker Ranch. The Bakers' home is a third of a mile away from oil wells and produced water pits that discharge into the irrigation system on their ranch. In theory, the impoundments clean the contaminated water by allowing heavy hydrocarbons, such as oil, to sink to the bottom of the pits and separate from the water produced during oil extraction. After separation, the water is permitted for discharge into the environment, where it is deemed clean by the state's standards. On the Baker ranch, the produced water is discharged into their irrigation system drains that flow into the Shoshone River system, then into Bighorn Lake and Montana. ${ }^{23}$

\footnotetext{
22 During the same time, Clark citizens collaborated with Global Community Monitor and Coming Clean to conduct bucket testing (Breech et al. 2014). Additionally, Thomas worked with Shale Test and Drew University to conduct more monitoring. Using particulate matter monitors and FLIR gas finder videography, they observed real-time emissions. They used SUMMA canisters to collect additional grab samples of air like the Tedlar bag/bucket samples as well as longer air samples.

23 The federal Clean Water Act provides that the discharge of any pollutants from a point source into surface water of the United States must be regulated under the Wyoming Pollutant Discharge Elimination System (WYPDES) Program. Through this program, operators of a point source discharge are required to receive coverage under a WYPDES permit containing limitations and conditions that protect the state's surface water quality standards.
} 


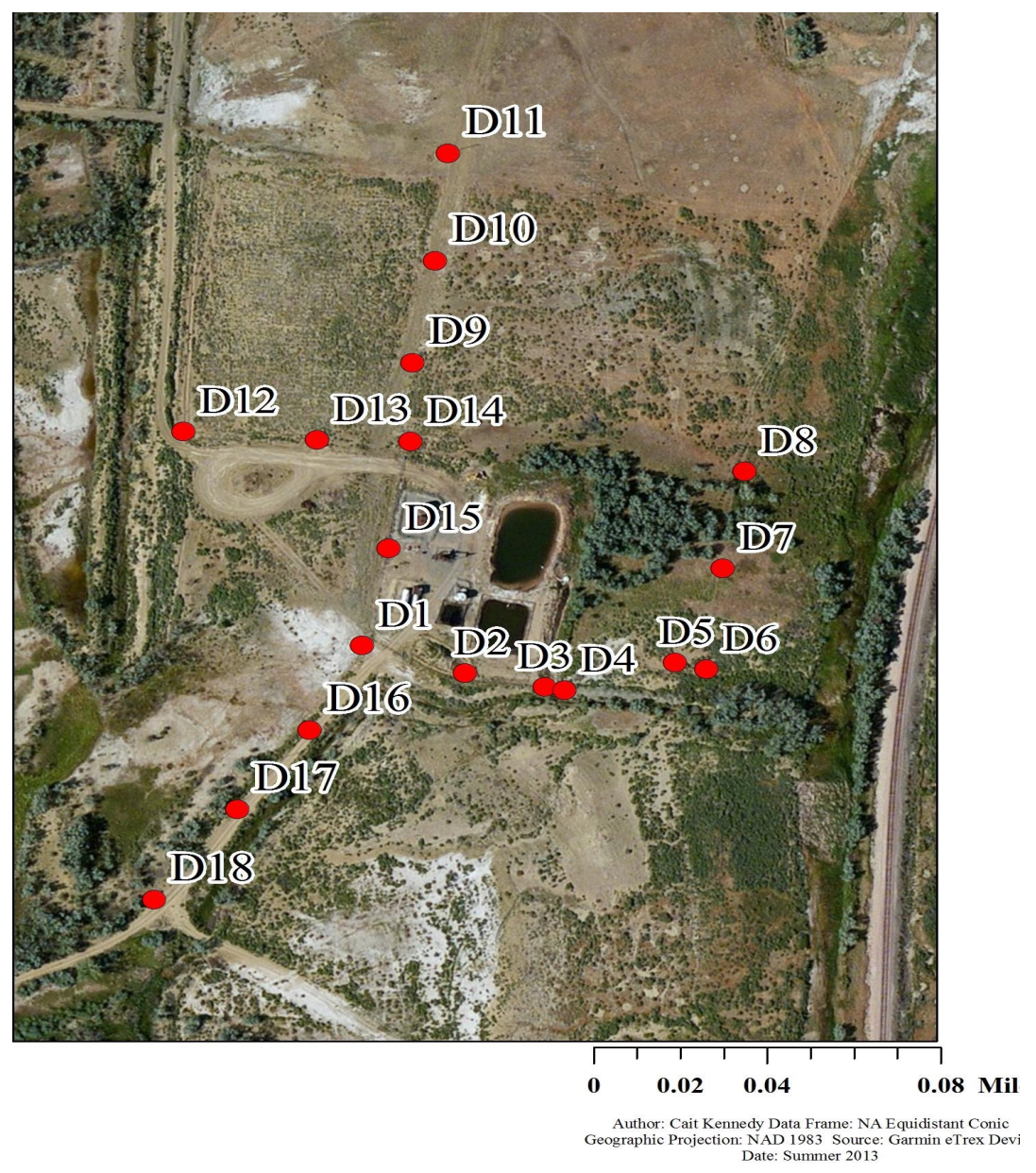

Figure 2: Photographic canisters testing locations on the Baker Ranch in Wyoming. Canisters were labeled and placed at set distances along roads surrounding a well. Image Courtesy of Caitlin Kennedy, 2013.

The overall goal for this first round of testing was to assess the feasibility for communities (rather than an environmental scientist with institutional support) to implement this method. Early on, we saw that the stress of running a ranch and monitoring the air at times might be too much. For instance, we postponed testing on the Bakers' property in the Spring of 2013 because of premature births in their goat herd. While they cannot ascribe $\mathrm{H}_{2} \mathrm{~S}$ as the cause, the Bakers have reason to suspect the goats' miscarriages and premature deaths were due to $\mathrm{H}_{2} \mathrm{~S}$ exposure (Xu et al. 1998). We also quickly realized that creating an evenly spaced testing grid, as frequently used in exposure studies, on a working ranch was not possible since the livestock 
grazed and wildlife inhabited the fields. ${ }^{24}$ In addition, the timeline for testing frequently extended beyond the 1 week or 1 month employed by Horwell (2005) due to inclement weather, and challenges the Baker and Thomas ranches faced in coordinating the project in tandem with other professional commitments. Subsequent papers on this project will discuss the challenges communities face in conducting this type of scientific testing.

Although the goal of this pilot test was merely to see if the tool was easily usable for communities, results revealed extraordinary levels of $\mathrm{H}_{2} \mathrm{~S}$ on the Bakers' property. The Bakers, Thomas, and her two interns conducted four rounds of testing for $\mathrm{H}_{2} \mathrm{~S}$-three trials of the photopaper and four grab samples of air. ${ }^{25}$ The grab samples of air were captured in Tedlar Bags, bags made from inert materials that are designed for collecting gases like $\mathrm{H}_{2} \mathrm{~S}$. The first photopaper test verified that photopaper test strips collocated in one place gave similar degrees of discoloration. For this test, the team placed six pairs of duplicate samples in locations chosen by the Bakers for one week. The duplicates all showed the same degree of discoloration, confirming the test's consistency.

Based on the success of this test, canisters were placed in 18 locations in places that were feasible and least disruptive according to the Bakers' suggestions. They focused on areas close to the wellpads, produced water impoundments, and discharge canals that emitted the strongest odors of $\mathrm{H}_{2} \mathrm{~S}$. Figure 2 shows a map of the photopaper canister testing locations they chose. They placed the canisters upside down and removed the caps so that air could flow into the canisters without exposing the photopaper to light. Two control canisters were left unopened and unexposed on the property. The control canisters ensure that exposure to air on the property produced tarnishing on the test strips rather than incidental exposures incurred while making and transporting the test strips. A week later, the team returned to pick up one canister at each location. The small canisters were difficult to find in the brush and some were knocked over and disturbed by livestock and wildlife. As a result, not all canisters were recovered. The field team capped each recovered canister and mailed the collection back to Northeastern, where we developed them in a standard photographic darkroom. The same process was repeated two weeks later. During this stage, the field team used four Tedlar bags to collect air samples. Tedlar

\footnotetext{
24 When Horwell et al. did their pilot study in New Zealand, they developed a grid system across the city of interest and placed the testing canisters conveniently in mailboxes. Cities are built on regular grids, but ranches are designed to handle livestock and maintain pastures, hence placing test canisters in the middle of grazing fields was not feasible.

25 With the help of Global Community Monitor and the Louisiana Bucket Brigade, the tedlar bag grab samples were collected and analyzed for sulfur compounds by the EPA-approved ASTM D 5504-08 method and VOC compounds using the EPA TO-15 modified method (Breech et al. 2014).
} 
bag samples were mailed to an accredited lab for volatile organic compound (VOC) and sulfuric compound analysis. ${ }^{26}$
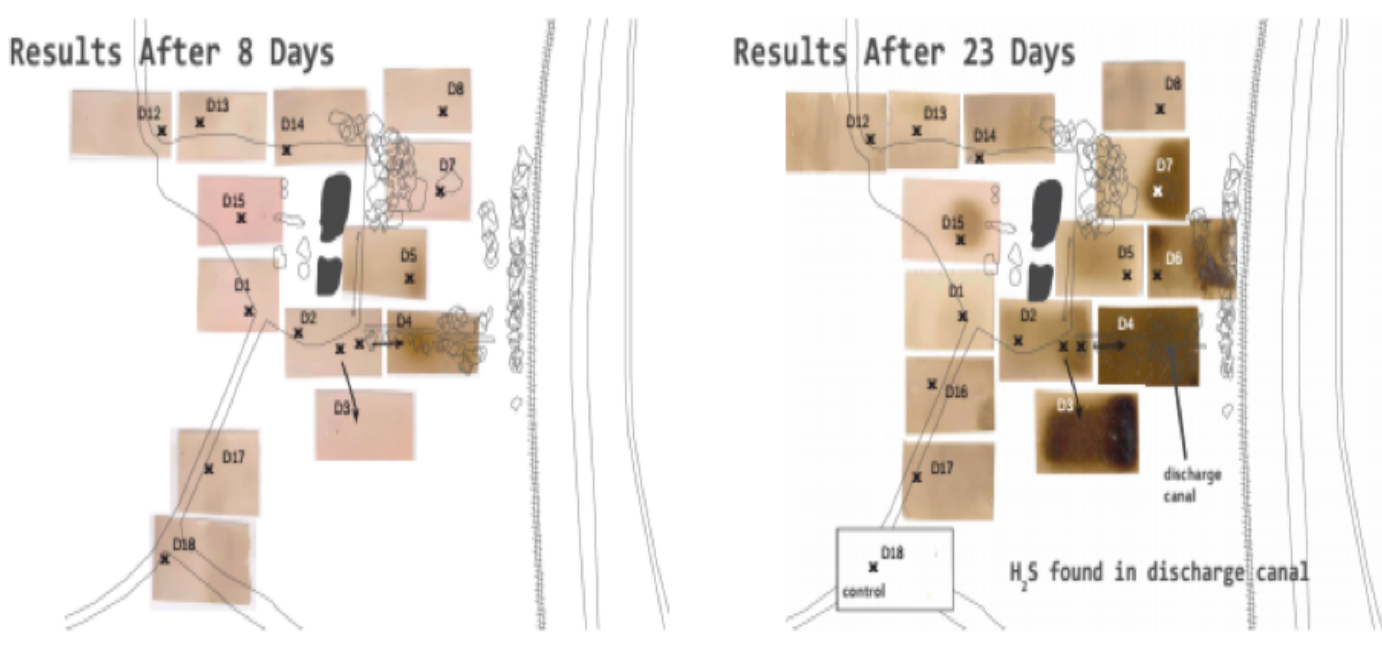

Figure 3: Map of tarnished $\mathrm{H}_{2} \mathrm{~S}$ photo strips at a well site on Baker Ranch. Tarnished photo strips show areas with higher levels of $\mathrm{H}_{2} \mathrm{~S}$. Points D9, D10 and D11 were compromised (knocked over or lost).

Figure 3 shows the photopaper results after 1 and 3 weeks. Clearly visible in this image is a significant darkening at both time points at the discharge canal (points D3 and D4). The film canister results correlate with the lab analysis for sulfur compounds in the four Tedlar bag air samples taken (see Figure 3). Each Tedlar bag sample showed high levels of $\mathrm{H}_{2} \mathrm{~S}$ and no significant amount of other corrosive compounds. This suggests that darkening of the photopaper was due to $\mathrm{H}_{2} \mathrm{~S}$. The Tedlar bag sample taken at the point of the discharge recorded a remarkable $48 \mathrm{ppm}$ of $\mathrm{H}_{2} \mathrm{~S}$. This value is 735 times greater than the exposure threshold recommended by the Agency for Toxic Substances and Disease Registry (ATSDR), and 48 times the 8-hour workplace exposure limit of $1 \mathrm{ppm}$ set by the American Conference of Governmental

${ }^{26}$ Volatile organic compounds (VOCs) are organic compounds that commonly evaporate from solids or liquids such as oil and natural gas. Many are hazardous to human health, including benzene, which is carcinogenic, along with toluene, ethylene, and xylene (Environmental Protection Agency 2017). 
Industrial Hygienists (ACGIH). Combining these two forms of visual and numeric data, we can now observe and quantify the previously invisible hazard emitted from the oil wells on the Bakers' ranch. Upon seeing the results, Patricia Baker remarked (see Figure 4):

I read it and I am appalled at the discharge canal, how toxic it is, when in fact it's supposed to be "clean"...Maybe I'm wrong, but if the $\mathrm{H}_{2} \mathrm{~S}$ is in there, you are not having clean water...that discharge canal is terribly filthy.

John asked:

Yeah, that's black [referring to the test strips] and that's terrible but is it still legal? I don't know. Yeah, so it's black, well maybe that just means nothing. You understand what I mean?

Both of these remarks illustrate that the images are readily interpretable for nonscientists, as both John and Patricia immediately identified the area of most concern. Furthermore, their quotes confirm the data's validity from their perspective, as the map supported their personal experiences.

The numeric result of $48 \mathrm{ppm}$ from the Tedlar bag air sample analysis assists in answering John's question. The Wyoming environmental regulatory threshold is that an average of $0.05 \mathrm{ppm}$ over 30 minutes is not to be exceeded more than two times per year. Even if the bucket measurement randomly captured the one and only release in that year, which would be highly unlikely, it still significantly exceeds Wyoming's regulatory threshold, since an emission of $48 \mathrm{ppm}$ collected over 1 minute averages to $1.6 \mathrm{ppm}$ over 30 minutes and $0.8 \mathrm{ppm}$ over 60 minutes.

John's question also shows how deeply embedded TLVs are as markers of safety. Either he implicitly assumes that the legal exposure limit is protective of human health or that the data is not actionable, "meaningful" in his parlance, if the legal limit is not exceeded. Both interpretations show either a faith in TLVs or that he feels his embodied experience of illness is insufficient to change the system without scientific data. 



Figure 4: The locations and results of bucket samples. The first image shows the Tedlar Bag results from bucket testing on the Baker Ranch at 4 locations. Note that the grab sample of air taken at the point of discharge had $48 \mathrm{ppm}$ of $\mathrm{H}_{2} \mathrm{~S}$. This finding is supported by image 2 which shows both the bucket results and the photopaper results together. Both methods showed the highest degree of $\mathrm{H}_{2} \mathrm{~S}$ at the point of discharge (Image Credit: Meghan McLaughlin 2013).

The most recent scientific work shows that chronic low levels of $\mathrm{H}_{2} \mathrm{~S}$ exposure are a health hazard and therefore any darkening on the strips should be a cause for further investigation. The way that $\mathrm{H}_{2} \mathrm{~S}$ is currently regulated rests on two interrelated assumptions: that $\mathrm{H}_{2} \mathrm{~S}$ exposure is primarily a danger for industrial workers, and that residents who live near $\mathrm{H}_{2} \mathrm{~S}$ oil and gas extraction are only at risk from anomalous accidental releases. The data-rich maps offered by the photopaper tool challenge both of these assumptions, showing that $\mathrm{H}_{2} \mathrm{~S}$ emissions likely extend beyond the workplace and that releases are not accidental and anomalous, but chronic and routine. 

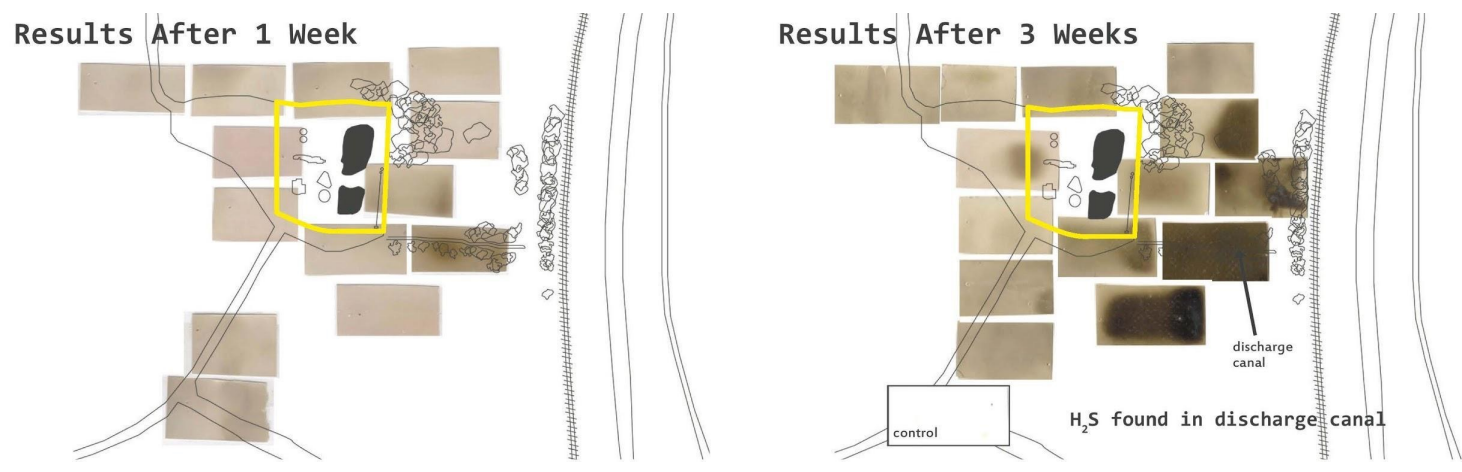

Figure 5: Boundaries of the leased well pad on the Baker Ranch. Note that the $\mathrm{H}_{2} \mathrm{~S}$ travels beyond the boundary of the well site note that the $\mathrm{H}_{2} \mathrm{~S}$ travels beyond the boundary of the well site onto the Bakers' property (Image Credit: Meghan McLaughlin 2013).

Examining the Bakers' photopaper maps, one can see that the "footprint" of the oil development extends well beyond the physical boundaries of the well pad, into the fields and irrigation systems of the Bakers' property (see Figure 5). All of the test strips on the Bakers' property were darkened compared to the untarnished controls. Strips located closer to the facility were darker than those placed farther away. The photopaper maps at the three other locations showed similar results. As shown in Figure 6, testing in Hamilton Dome oil field showed $\mathrm{H}_{2} \mathrm{~S}$ likely travelling from the oil field, along the water discharge canals, and into the air along public roads. The discharge canals feed into Cottonwood Creek, a waterway that runs through nearby Legend Rock State Park. The park is frequently visited for its ancient petroglyphs, some dating back 10,000 years. The protected site contains at least 283 different petroglyphs on 92 individual sandstone "panels."

The discoloration of the photopaper test strips in the state park, shown in Figure 7, along with the testing team's report of rotten egg smells, suggests that $\mathrm{H}_{2} \mathrm{~S}$ is traveling from Hamilton Dome oil field into publicly owned spaces. Similarly, results from testing in Elk Basin oil field showed strong discoloration along well-travelled public roads. Taken together, data from these four sites challenge the primary assumption that $\mathrm{H}_{2} \mathrm{~S}$ exposure is limited to the workplace. 


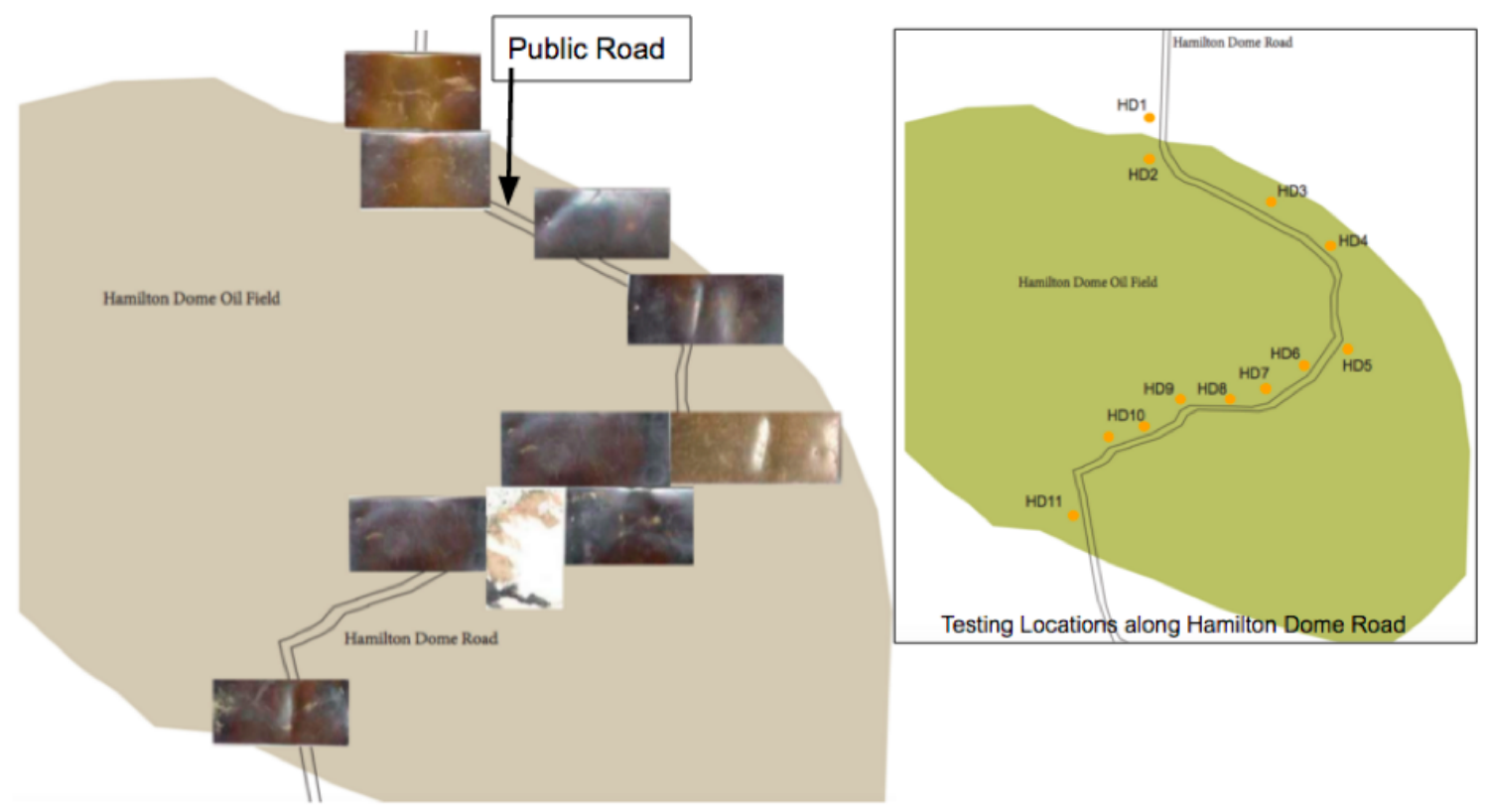

Figure 6: Shows results from testing along the well-travelled public road in Hamilton Dome oil field. All recovered test strips showed tarnishing suggesting that $\mathrm{H}_{2} \mathrm{~S}$ from the field is contaminating public roads (Image Credit: Meghan McLaughlin 2013).

Furthermore, data gathered during different seasons and time spans in the four Wyoming locations all showed evidence of accumulated, non-accidental emissions. Testing locations with the highest levels of $\mathrm{H}_{2} \mathrm{~S}$ (see point D4 in Figure 3) remained consistent across time periods. This suggests that at these locations $\mathrm{H}_{2} \mathrm{~S}$ is chronically present. Results left for the shorter time period in each location were consistently lighter than results left out for a longer period of time. This suggests that the $\mathrm{H}_{2} \mathrm{~S}$, which darkened these strips, was released not just at one time but repeatedly across a longer period of time. If the darkening of strips had been due to an accidental release, the test strips analyzed before the release would resemble controls and those after the release would have been darkened to the same extent, regardless of how long they were left out. 

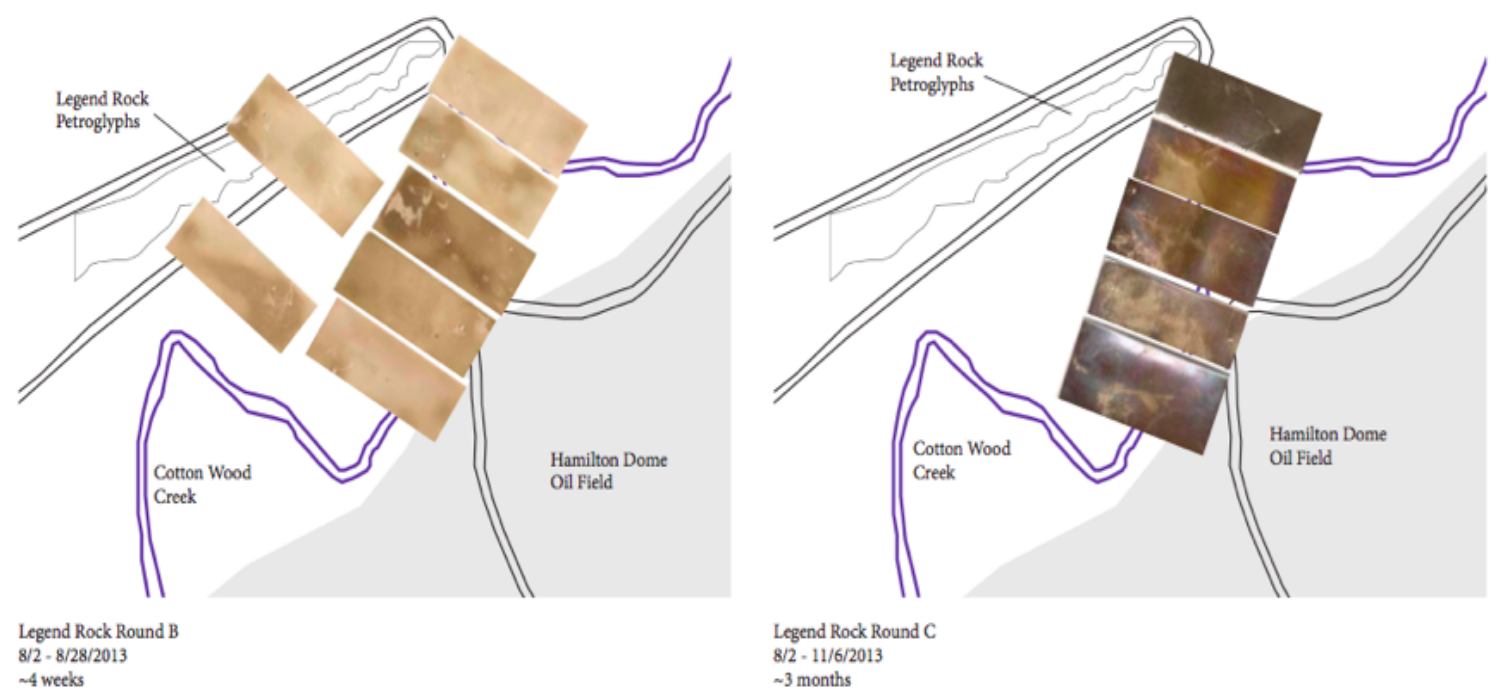

Figure 7: Map of tarnished $\mathrm{H}_{2} \mathrm{~S}$ photo strips at Legend Rock State Park over four weeks (upper left) and three months (upper right) (Image Credit: Meghan McLaughlin 2013).

These results provide useful evidence that it is inappropriate to regulate only accidental releases of $\mathrm{H}_{2} \mathrm{~S}$ during oil and gas development as currently provided by its designation as an EHS under 112 (b). Section 112 (b) is "not designed [n]or intended to address [the] daily toxic exposures" (Sierra Club 2009, 1) experienced by Wyoming gas patch residents and evidenced by our data-rich maps. Our findings support the conclusion that EPA's current approach to $\mathrm{H}_{2} \mathrm{~S}$ monitoring and regulation during oil and gas extraction is inappropriate and insufficient. By showing that $\mathrm{H}_{2} \mathrm{~S}$ emissions are chronically released in these four oil and gas fields, our results support the listing of $\mathrm{H}_{2} \mathrm{~S}$ as an $\mathrm{HAP}$, to manage and prevent chronic, long term community exposure by mandatory reporting and adherence to national emissions standards that would limit releases.

This example supports the approach of using STS to shift the ecology of environmental monitoring tools from one that sustains regimes of imperceptibility to a new ecology of tools containing sensing devices that render community exposure experiences more evident. Rather than suggesting there is a hierarchy of environmental monitoring tools, we argue for expanding the ecology of existing testing tools to produce testing methods and forms of data that are more suited towards community monitoring. Aligning with Calvillo's description of environmental monitoring tools as having different "performative capacities," or "properties and opportunities," 
depending on the social and political contexts of their use, the photopaper provides communities a longitudinal landscape view of $\mathrm{H}_{2} \mathrm{~S}$ emissions that contextualizes and compliments Tedlar bag measurements of individual time points (Calvillo González 2014, 23). Additionally, the photopaper's low cost and relative simplicity make the method more feasible than Jerome meters for community members. When used in conjunction with other tools such as the Tedlar bag samples on the Bakers' property, the photopaper method provides new ways to dynamically challenge the imperceptibility of chronic $\mathrm{H}_{2} \mathrm{~S}$ exposure. The maps themselves potentially assist in building a sense of community among exposed people. Anybody who travels or is familiar with these landscapes can now visualize for themselves and present a materialized representation of their exposure to others. Therefore, the data-rich $\mathrm{H}_{2} \mathrm{~S}$ maps can evidence the shared problem of chronic $\mathrm{H}_{2} \mathrm{~S}$ exposure and challenge regulatory norms.

\section{An Expanding Ecology of Tools for Environmental Monitoring}

As Beck describes, the invisibility and latency of late industrial hazards create challenges to ascribing culpability for contamination and harm (Beck 1992). The sciences and social sciences can collaborate to create a socio-technical sensorium that is better tuned to tracking industrial contamination. This in part can be achieved by rethinking the design of sensing instrumentation to bring their indexical elements to the surface. Creating sensing systems that make emissions and contamination visible and thereby collectively witnessable could assist in creating accountability for contamination events (Kuchinskaya 2017), such as illustrating that $\mathrm{H}_{2} \mathrm{~S}$ emissions are chronic and routine rather than periodic and accidental.

To further validate the photographic paper tool and develop ways for communities' results to be credible to regulatory agencies, we received three years of funding from Harvard School of Public Health to develop quality control and quality assurance processes for testing. In terms of quality control, we are developing protocols for positive and negative controls that show the photopaper method has been properly implemented. To assess the accuracy of communities' testing results, we are evaluating ways to combine the photopaper tool with other $\mathrm{H}_{2} \mathrm{~S}$ sensing methods such as Tedlar bags to support their results. To increase credibility in the academic scientific community for these methods, we will publish our results in scientific articles as well as on Public Lab. How-to guides and kits will then be developed for other communities to use.

Illustrating how data from an ecology of sensing approaches can be brought together to support others' findings, we co-map the results from the Tedlar bags with the photopaper (see Figure 4). In these maps, we present the numeric data as vertical columns rising from the spot 
where the samples were taken within the landscape. Emplacing the data within a map of the location rather than in an auxiliary bar chart reminds the viewers that these are not abstract numbers but physical quantities of a toxic gas found on a person's property (see Figure 4). These columns exceed the frame to picture in order to emphasize the exceptional risk posed by such as concentration at these points.

As we validate the photopaper tool, we will also be studying whether $\mathrm{H}_{2} \mathrm{~S}$ exposure from oil and gas extraction occurs systematically and across states. We are testing it in three other locations-Texas, New Mexico and Washington-and collaborating with national organizations such as Earthworks' Oil and Gas Accountability Project and Shale Test to share results from this testing. Because online communities cannot replace person-to-person community, Thomas is funded through this grant to lead fieldwork in new communities and build collaborations between communities in the three testing locations. Collectively, the data from this project could illustrate the need for federal monitoring of $\mathrm{H}_{2} \mathrm{~S}$ during oil and gas production. Methodologically, indexical approaches to mapping environmental hazards could be adopted for monitoring other forms of environmental contamination such as formaldehyde and particulate matter.

Changing instrumentation alone will not address the profound asymmetries between community and industrial capacity to generate technical systems and data or the ability to capture regulation and influence research. However, an STS-informed, indexical approach is an important aspect of creating the possibility of both industrial accountability and a more civic form of science that serves public interest (see Fortun and Fortun 2005 and the introduction to this thematic collection). The photopaper project attempts to support community mobilization by expanding the ecology of sensing tools to include systems that make visible and enable collective articulation of shared risk and exposure experiences. The photopaper should not be misrecognized as a replacement to tools like the Jerome meter. As an index, photographic paper only captures a trace of industrial emissions and cannot represent all aspects of emissions in their entirety. Rather, it is a complementary approach that articulates how a device like the Jerome works, opening its black box to the possibility of collective and speculative redesign: could a community scale up a version of the Jerome, creating a large-scale gold plate that is a permanent fixture outside a $\mathrm{H}_{2} \mathrm{~S}$ emitting industry? The photopaper also offers an alternative way of seeing this contaminant that is suitable to tracking and mapping its spread through a landscape over time, rather than tracking concentrations in a workplace. The performative capacity of the photopaper's data-rich maps communicates contamination in a way that numerical expression of concentrations often fail to do. In effect, data-rich maps materialize exposure by illustrating contamination across a space effectively by physically, i.e. indexically, recording and representing 
damage from the contaminant.

The process of developing this sensing system expresses that STS ideas can inform the redesign of instrumentation to make a material difference in how environmental monitoring is practiced. To truly counter the influence of industry interests on regulation at the state and federal level, communities need the means to connect and scale their experience in a similar fashion to industries. An STS-informed ecology of tools for environmental science that supports the growth of a grassroots research infrastructure is required to reveal when and if contamination events are systemic rather than accidental across this industrial system. This process for mapping $\mathrm{H}_{2} \mathrm{~S}$ could in the long term become part of an infrastructure comprised of more affordable open source tools designed to produce data that charismatically express exposure experiences that, when interconnected across geographic areas, make visible the consequences of industrial processes on human lives and environments.

\section{Author Biography}

Sara Wylie is an Assistant Professor of Sociology/Anthropology and Health Sciences in Northeastern University's Social Science Environmental Health Research Institute. Wylie is a cofounder of Public Lab and EDGI, the Environmental Data and Governance Initiative. Wylie seeks to develop research tools, collaborations and platforms for studying and creating accountability for the fossil fuel and allied petrochemical industries. She has a forthcoming book with Duke University Press on the U.S. boom in unconventional energy production titled: Fractivism Corporate Bodies and Chemical Bonds.

\section{Author Biography}

Elisabeth Wilder is a PhD candidate in Sociology at Northeastern University. She is a research associate with the Northeastern Environmental Justice Research Collaborative and a member of the Social Science Environmental Health Research Institute. Her research centers on communitybased movements for environmental health and justice.

\section{Author Biography}

Lourdes Vera is a PhD student in Sociology and a member of the Social Science Environmental Health Research Institute at Northeastern University. She is also a member of the Environmental 
Data and Governance Initiative (EDGI) and exploring questions around environmental justice and data accessibility through community based participatory research.

\section{Author Biography}

Deb Thomas is a $4^{\text {th }}$ generation Red Lodge, Montana, native. She and her husband Dick Bilodeau raised their family in Clark, Wyoming, on the Eastern side of Yellowstone Park, along the Beartooth Front of the Rocky Mountains. Deb began working on oil and gas issues in 1999 when a drill rig began operations 600 yards from her home. She organized the Clark Resource Council (CRC) and the Pavillion Area Concerned Citizens (PACC); both effective affiliates of Powder River Basin Resource Council. She has raised the awareness of local, state and federal elected and appointed government officials and developed strong working relationships with impacted residents, Tribal members and other stakeholders affected by fossil fuels development.

\section{Author Biography}

Megan McLaughlin is a landscape architect and artist based in Oakland, CA.

\section{Acknowledgments}

We would like to thank the Baker family and community members we worked with in Wyoming to develop this method. We also give our appreciation to Public Lab for creating and sustaining a space for sharing and further developing the photopaper tool. Many thanks also to Bruce Hamilton and The Department of Arts + Design at Northeastern University for providing us access to their darkroom. Dietmar Offenhuber's Indexical Design Symposium inspired the framing of this paper. The STS Underground Conference at the Colorado School of Mines and Northeastern University's Social Science Environmental Health Research Institute provided great intellectual community for further workshopping this paper. For more images and details on development of the research described here please visit: https://publiclab.org/notes/Sara/ 09-13-2017/ about-hydrogen-sulfide-research-paper-materializing-exposure? =1505338152.

\section{References}

Adams, Crystal, Phil Brown, Rachel Morello-Frosch, Julia Green Brody, Ruthann Rudel, Ami 
Zota, Sarah Dunagan, Jessica Tovar, and Sharyle Patton. 2011. "Disentangling the Exposure Experience: The Roles of Community Context and Report-Back of Environmental Exposure Data." Journal of Health and Social Behavior 52 (2): 180-196.

Allen, Barbara. 2003. Uneasy Alchemy: Citizens and Experts in Louisiana's Chemical Corridor Disputes. MIT Press.

Allen, Barbara. 2004. "Shifting Boundary Work: Issues and Tensions in Environmental Health Science in the Case of Grand Bois, Louisiana." Science as Culture 13 (4): 429-448.

Allen, Joseph, David L. MacIntosh, Lori E. Saltzman, Brian J. Baker, Joanna M. Matheson, Joel R. Recht, Taeko Minegishi, et al. 2012. "Elevated Corrosion Rates and Hydrogen Sulfide in Homes with 'Chinese Drywall.'” Science of the Total Environment 426: 113-119.

Arizona Instrument, LLC. 2015. “User Manual: Jerome ${ }^{\circledR}$ J605 Hydrogen Sulfide Analyzer." www.azic.com/wp-content/uploads / 2015 / ... / 700-0108-H_MANUAL-Jerome-J605.pdf.

Auyero, Javier, and Débora Alejandra Swistun. 2009. Flammable: Environmental Suffering in an Argentine Shantytown. Oxford University Press.

Beck, Ulrich. 1992. Risk Society: Towards a New Modernity. Vol. 17. Sage.

Bowler, Tim. 2015. "Falling Oil Prices: Who Are the Winners and Losers?" BBC News, January 19, sec. Business. http: / / www.bbc.com/news / business-29643612.

Breech, Ruth, Caroline Cox, Elizabeth Crowe, Jessica Hendricks, and Denny Larson. 2014. Warning Signs: Toxic Air Pollution Identified at Oil and Gas Sites. Coming Clean and Global Community Monitor. http: / / comingcleaninc.org/warning-signs.

Buckley, Chris, and Adam Wu. 2015. "Amid Smog Wave, an Artist Molds a Potent Symbol of Beijing's Pollution." The New York Times, December 1. https://www.nytimes.com/ 2015/12 / 02 / world / asia / beijing-smog-air-pollution-artist-brick.html?smid=plshare\&_r=0.

Bullard, Robert D., and Beverly H. Wright. 1990. "The Quest for Environmental Equity: Mobilizing the African-American Community for Social Change." Society \& Natural Resources 3 (4): 301-311.

Burri, Regula Valérie, and Joseph Dumit. 2008. "13 Social Studies of Scientific Imaging and Visualization." The Handbook of Science and Technology Studies, 297.

Calvillo González, Nerea. 2014. "Sensing Aeropolis. Urban Air Monitoring Devices in Madrid, 2006-2010." PhD Diss., Arquitectura. http://oa.upm.es/30925/1/ NEREA_CALVILLO_GONZALEZ.pdf.

Clarke, Adele E, and Joan Fujimura, eds. 1992. The Right Tools for the Job: At Work in Twentieth Century Life Sciences. Princeton, NJ: Princeton University Press. 
Connor, Steven. 2005. "The Menagerie of the Senses." In Sixth Synapsis Conference, I Cinque Sensi (per Tacer Del Sesto). Bertinoro, Italy. http:/ / stevenconnor.com/menagerie.html.

Corburn, Jason. 2005. Street Science: Community Knowledge and Environmental Health Justice. MIT Press.

Daston, Lorraine, and Peter Galison. 2007. Objectivity. New York: Zone Books.

Department of Transportation. 2012. "Transportation." Code of Federal Regulations, Title 49. Pipeline and Hazardous Materials Safety Administration, .

Dosemagen, Shannon, Jeffrey Warren, and Sara Wylie. 2011. "Grassroots Mapping: Creating a Participatory Map-Making Process Centered on Discourse." Journal of Aesthetics and Protest 8. http://joaap.org/issue8/finals/public-lab/public\%20lab\%20web(rough $\%$ 20final).doc.

Dumit, Joseph. 2004. Picturing Personhood: Brain Scans and Biomedical Identity. Princeton University Press.

Environmental Protection Agency. 1993. "Report to Congress on Hydrogen Sulfide Air Emissions Associated with the Extraction of Oil and Natural Gas." http://www.gpo.gov/fdsys / pkg/ FR-1994-08-22/html/94-20556.htm.

Environmental Protection Agency. 1994. "Hydrogen Sulfide; Methyl Mercaptan; Toxic Chemicals Release Reporting; Community Right-to-Know; Stay of Reporting Requirements." Federal Register 96 (161). http: / / www.gpo.gov/fdsys/pkg/FR-1994-08-22/html/94-20556.htm.

Environmental Protection Agency. 2011. "Hydrogen Sulfide; Community Right-to-Know Toxic Chemical Release Reporting." Federal Register 76 (200). https://www.epa.gov/toxicsrelease-inventory-tri-program/lifting-administrative-stay-hydrogen-sulfide.

Environmental Protection Agency. 2017. "Method 9 - Visual Determination of the Opacity of Emissions From Stationary Sources." Code of Federal Regulations, Title 40. Protection of the Environment, July. https://www.ecfr.gov/cgi-bin/text-idx? $\mathrm{SID}=4 \mathrm{~d} 3 \mathrm{f} 645 \mathrm{~d} 86 \mathrm{ce} 9 \mathrm{f} 3 \mathrm{cc} 128 \mathrm{e} 20 \mathrm{c} 2 \mathrm{fb} 317 \mathrm{fa} \& \mathrm{mc}=$ true\&node=pt40.8.60\&rgn=div5.

Environmental Protection Agency. 2017. “Volatile Organic Compounds' Impact on Indoor Air Quality." Overviews and Factsheets. Accessed May 12. https://www.epa.gov/indoorair-quality-iaq/volatile-organic-compounds-impact-indoor-air-quality.

Finnbjornsdottir, Ragnhildur Gudrun, Hanne Krage Carlsen, Throstur Thorsteinsson, Anna Oudin, Sigrun Helga Lund, Thorarinn Gislason, and Vilhjalmur Rafnsson. 2016. "Association between Daily Hydrogen Sulfide Exposure and Incidence of Emergency Hospital Visits: A Population-Based Study." PloS One 11 (5): e0154946.

Fortun, Kim, and Mike Fortun. 2005. "Scientific Imaginaries and Ethical Plateaus in 
Contemporary US Toxicology." American Anthropologist 107 (1): 43-54.

Frickel, Scott, Sahra Gibbon, Jeff Howard, Joanna Kempner, Gwen Ottinger, and David J. Hess. 2010. “Undone Science: Charting Social Movement and Civil Society Challenges to Research Agenda Setting." Science, Technology, \& Human Values 35 (4): 444-473.

Gabrys, Jennifer. 2016. Program Earth: Environmental Sensing Technology and the Making of a Computational Planet. University of Minnesota Press. https:/ / muse.jhu.edu/book/45371.

Galison, Peter. 1997. Image and Logic: A Material Culture of Microphysics. University of Chicago Press.

Gold, Russell, and Tom McGinty. 2013. “Energy Boom Puts Wells in America's Backyards.” Wall Street Journal 25.

Haraway, Donna. 1991. Simians, Cyborgs, and Women: The Reinvention of Nature. Routledge.

Haraway, Donna. 1997. Modest_Witness@ Second_Millennium. FemaleMan@ _Meets_OncoMouseTM. Routledge.

Horwell, Claire, Andrew G. Allen, Tamsin A. Mather, and John E. Patterson. 2004. "Evaluation of a Novel Passive Sampling Technique for Monitoring Volcanogenic Hydrogen Sulfide." Journal of Environmental Monitoring 6 (7): 630-635.

Horwell, Claire, J. E. Patterson, J. A. Gamble, and A. G. Allen. 2005. “Monitoring and Mapping of Hydrogen Sulphide Emissions Across an Active Geothermal Field: Rotorua, New Zealand." Journal of Volcanology and Geothermal Research 139 (3): 259-269.

Jain, S. Lochlann. 2013. Malignant: How Cancer Becomes Us. Univ of California Press.

Jäppinen, P., V. Vilkka, O. Marttila, and T. Haahtela. 1990. "Exposure to Hydrogen Sulphide and Respiratory Function." British Journal of Industrial Medicine 47 (12): 824-828.

Jeremijenko, Natalie. 2000. OneTrees. http://www.nyu.edu/projects/xdesign/onetrees/sites/ sites.html. Also, see Media, Art, Net's entry on the project: http:// www.medienkunstnetz.de/works/one-trees/.

Kilburn, Kaye H. 2012. "Human Impairment from Living Near Confined Animal (Hog) Feeding Operations." Journal of Environmental and Public Health 2012. https: / / www.hindawi.com/ journals / jeph/2012/565690/abs/.

Kilburn, Kaye H., Jack D. Thrasher, and Michael R. Gray. 2010. “Low-Level Hydrogen Sulfide and Central Nervous System Dysfunction." Toxicology and Industrial Health. http:// tih.sagepub.com/content/early/2010/05/05/0748233710369126.

Kohler, Robert E. 1994. Lords of the Fly: Drosophila Genetics and the Experimental Life. University of Chicago Press.

Kornblug, Sophie. 2014. “Sensing Hydrogen Sulfide from CAFO Emissions in Poweshiek County, 
Iowa." Public Lab: A DIY Environmental Science Community. https: / publiclab.org/notes / sophie / 07-16-2014/ sensing-hydrogen-sulfide-from-cafo-emissions-in-poweshiek-countyiowa.

Kuchinskaya, Olga. 2017. "Connecting the Dots: Public Engagement with Environmental Data." Environmental Communication, March.

Laffont, Jean-Jacques, and Jean Tirole. 1991. "The Politics of Government Decision-Making: A Theory of Regulatory Capture." The Quarterly Journal of Economics 106 (4): 1089-1127.

Landecker, Hannah. 2007. Culturing Life: How Cells Became Technologies. Harvard University Press.

Larson, Denny, Ruth Breech, Jessica Hendricks, Mark Chernaik, Amy Mall, Frank Smith, Josh Joswick, and Mike Eisenfeld. 2011. GASSED! Citizen Investigation of Toxic Air Pollution from Natural Gas Development. Global Community Monitor. http:// www.arkansasfracking.org/GCM-gassedreport.pdf

Latour, Bruno. 1986. “Visualization and Cognition.” Knowledge and Society 6 (6): 1-40.

Latour, Bruno. 1987. Science in Action: How to Follow Scientists and Engineers through Society. Cambridge, MA: Harvard University Press.

Latour, Bruno. 1990. "Drawing Things Together." In Representation in Scientific Practice, edited by M. Lynch and S. Woolgar, 19-68. Cambridge, MA: MIT Press. http: / www.citeulike.org/ group/10888/article/ 449517.

Latour, Bruno, and Steve Woolgar. 1986. Laboratory Life: The Construction of Scientific Facts. Princeton, NJ: Princeton University Press.

Legator, Marvin S., Chantele R. Singleton, Debra L. Morris, and Donna L. Philips. 2001. "Health Effects from Chronic Low-Level Exposure to Hydrogen Sulfide." Archives of Environmental Health: An International Journal 56 (2): 123-131. doi: $10.1080 / 00039890109604063$.

Liboiron, Max. 2015. “BabyLegs.” Civic Laboratory. https:// civiclaboratory.nl/2015/05/31/ babylegs/.

Lodge, James P. 1988. Methods of Air Sampling and Analysis. CRC Press.

Lynch, Michael, and Steve Woolgar. 1990. Representation in Scientific Practice. MIT press. http:// eureka.sbs.ox.ac.uk/id/eprint/117.

Macey, Gregg P., Ruth Breech, Mark Chernaik, Caroline Cox, Denny Larson, Deb Thomas, and David O. Carpenter. 2014. "Air Concentrations of Volatile Compounds Near Oil and Gas Production: A Community-Based Exploratory Study." Environmental Health 13 (1): 82.

Moore, Christopher W., Barbara Zielinska, Gabrielle Petron, and Robert B. Jackson. 2014. "Air Impacts of Increased Natural Gas Acquisition, Processing, and Use: A Critical Review." 
Environmental Science \& Technology 48 (15): 8349-8359.

Morris, Jim. 1997. "The Brimstone Battles; Lost Opportunity; EPA Had Its Chance to Regulate Hydrogen Sulfide." The Houston Chronicle, November 9.

Morton, Chester M. 2008. "Jerome Meter Measurement Variability." Proceedings of the Water Environment Federation 2008 (4): 24-34.

Murphy, Michelle. 2004. "Uncertain Exposures and the Privilege of Imperception: Activist Scientists and Race at the US Environmental Protection Agency." Osiris 19: 266-282.

Murphy, Michelle. 2006. Sick Building Syndrome and the Politics of Uncertainty: Environmental Politics, Technoscience and Women Workers. Durham, N.C.: Duke University Press.

Occupational Safety and Health Administration. 2017. "Hydrogen Sulfide - Hazards." Accessed July 21. https: / / www.osha.gov/SLTC/hydrogensulfide/ hazards.html.

Offenhuber, Dietmar, and Orkan Telhan. 2015. "Indexical Visualization- The Data-Less Information Display." Ubiquitous Computing, Complexity and Culture, 288.

Ottinger, Gwen. 2010a. "Buckets of Resistance: Standards and the Effectiveness of Citizen Science." Science, Technology, E Human Values 35 (2): 244-270.

Ottinger, Gwen. 2010b. "Epistemic Fencelines: Air Monitoring Instruments and Expert-Resident Boundaries." Spontaneous Generations: A Journal for the History and Philosophy of Science 3 (1): 55-67.

Peirce, Charles S., Charles Hartshorne, Paul Weiss, and Arthur W. Burks. 1960. "Division of Signs." In Collected Papers of Charles Sanders Peirce. Cambridge: BelkPress of Harvard University Press.

Pine, Kathleen H., and Max Liboiron. 2015. "The Politics of Measurement and Action." In Proceedings of the 33rd Annual ACM Conference on Human Factors in Computing Systems, 3147-3156. CHI '15. New York, NY, USA: ACM. doi:10.1145/2702123.2702298.

Ratto, Matt. 2011. “Critical Making: Conceptual and Material Studies in Technology and Social Life." The Information Society 27 (4): 252-260.

Rheinberger, Hans-Jorg. 1997. Toward a History of Epistemic Things: Synthesizing Proteins in the Test Tube. Palo Alto: Stanford University Press.

Schinasi, Leah, Rachel Avery Horton, Virginia T. Guidry, Steve Wing, Stephen W. Marshall, and Kimberly B. Morland. 2011. "Air Pollution, Lung Function, and Physical Symptoms in Communities Near Concentrated Swine Feeding Operations." Epidemiology 22 (2): 208215.

Sellers, Christopher C. 1997. Hazards of the Job: From Industrial Disease to Environmental Health Science. Univ of North Carolina Press. 
Shapin, Steven, and Simon Schaffer. 1985. Leviathan and the Air-Pump: Hobbes, Boyle, and the Experimental Life (New in Paper). Princeton University Press.

Shapiro, Nicholas. 2015. "Attuning to the Chemosphere: Domestic Formaldehyde, Bodily Reasoning, and the Chemical Sublime." Cultural Anthropology 30 (3): 368-393.

Shea, Ellyn. 2014. "OneTrees: The Forgotten Tree Art Project." Deeproot. http:// www.deeproot.com/blog/blog-entries / onetrees-the-forgotten-tree-art-project.

Sierra Club. 2009. "RE: Hydrogen Sulfide Needs Hazardous Air Pollutant Listing under CAA Title III." https: / / www.earthworksaction.org/ files/publications / H2SLetterToEPA.pdf.

Skrtic, L. 2006. “Hydrogen Sulfide, Oil and Gas, and People's Health." Diplomski Rad. Berkeley: University of California.

Smith, Grant. 2014. “U.S. Overtakes Saudi Arabia and Russia as Largest Oil Producer.” http:// instituteforenergyresearch.org/analysis / u-s-overtakes-saudi-arabia-russia-worldsbiggest-oil-producer/.

Thomas, Deborah. 2006. “When a Gas Pipeline Blows, You Get Out Fast.” http:/ / www.hen.org/ issues /332/16638.

Thomas, Deborah. 2014. Breathe at Your Own Risk. Unpublished Report on Wyoming Community Monitoring.

Traweek, Sharon. 1992. Beamtimes and Lifetimes. Harvard University Press.

Tufte, Edward R., Susan R. McKay, Wolfgang Christian, and James R. Matey. 1998. "Visual Explanations: Images and Quantities, Evidence and Narrative." Computers in Physics 12 (2): 146-148.

United Postal Service. 2017. "UPS Guide for Shipping Ground and Air Hazardous Material." https: / / www.ups.com/content/us/en/ resources/ship/hazardous.

U.S. Department of Labor, Bureau of Labor Statistics. 2015. “Fatal Occupational Injuries Incurred by Contracted Workers, 2011-2014," In Cooperation with State, New York City, District of Columbia, and Federal Agencies, Census of Fatal Occupational Injuries, . http:// www.bls.gov/iif/oshwc/cfoi / contractor.pdf.

Wallis, Brian, and Jeffrey Kastner. 2010. Land and Environmental Art. London: Phaidon Press Limited. https: / / philpapers.org/rec/KASLAE.

Wing, Steve, Rachel Avery Horton, Stephen W. Marshall, Kendall Thu, Mansoureh Tajik, Leah Schinasi, and Susan S. Schiffman. 2008. "Air Pollution and Odor in Communities Near Industrial Swine Operations." Environmental Health Perspectives 116 (10): 1362.

Wylie, Sara. 2011. "Corporate Bodies and Chemical Bonds: An STS Analysis of Natural Gas Development in the United States." Massachusetts Institute of Technology. https:// 
dspace.mit.edu/handle/1721.1/69453.

Wylie, Sara, and Len Albright. 2014. "WellWatch: Reflections on Designing Digital Media for Multi-Sited Para-Ethnography." Journal of Political Ecology 21 (1): 321-348.

Wylie, Sara, Kirk Jalbert, Shannon Dosemagen, and Matt Ratto. 2014. "Institutions for Civic Technoscience: How Critical Making Is Transforming Environmental Research." The Information Society 30 (2): 116-126.

Wylie, Sara, and Deborah Thomas. 2014. "New Tools for Detecting and Communicating Environmental Exposures and Risks Associated with Oil and Gas Extraction." Partnerships for Environmental Public Health, National Institute of Environmental Health Science, Annual Meeting: "New Tools for Detecting and Communicating Environmental Exposures and Risks associated with Oil and Gas Extraction." September $22^{\text {nd }}$

Xu, Xiping, Sung-Il Cho, Mary Sammel, Liangya You, Shangcong Cui, Yinmin Huang, Guohong Ma, et al. 1998. "Association of Petrochemical Exposure with Spontaneous Abortion." Occupational and Environmental Medicine 55 (1): 31-36. 